\title{
The dynamics of land use/land cover change modeling and their implication for the flood damage assessment in the Tondano watershed, North Sulawesi, Indonesia
}

\author{
Fajar Yulianto $^{1} \cdot$ Indah Prasasti $^{1} \cdot$ Junita Monika Pasaribu $^{2} \cdot$ Hana Listi Fitriana ${ }^{1}$. \\ Zylshal $^{1} \cdot$ Nanik Suryo Haryani $^{1} \cdot$ Parwati Sofan $^{1}$
}

Received: 22 February 2016/ Accepted: 27 February 2016/Published online: 12 March 2016

(c) Springer International Publishing Switzerland 2016

\begin{abstract}
The Markov Chain and Cellular Automata (Markov-CA) approach have been applied to create the dynamics of land use/land cover (LULC) change modeling in the Tondano watershed, North Sulawesi, Indonesia. The multi temporal of remotely sensed data, Landsat $5 \mathrm{TM}$ in 1997, Landsat 7 TM in 2002 and Landsat 8 LDCM in 2015 were used to produce the LULC maps. Advanced Spaceborne Thermal Emission and Reflection Radiometer (ASTER) Global Digital Elevation Map (GDEM) data were used as input for the flood modeling created by the Monte Carlo algorithm. The LULC maps in 1997 and 2002 were used to create predictions and modeling LULC map with the Markov-CA approach in the next few years (for the year 2015, 2025, 2035 and 2050). Meanwhile, the LULC map in 2015 with an accuracy of $80.11 \%$ based on the calculation of the Kappa index has been used as a reference map to determine the accuracy of the MarkovCA approach to produce a model of the LULC map in 2015. The result of the accuracy by using cross-correlation matrix between the LULC model in 2015 with the LULC reference in 2015 is $75.88 \%$. The dynamics of LULC changes showed that area-class forest, dry land, paddy fields and shrubbery would be expected to experience an area decreases in the extent from the year 2015 to 2050 , with the rate of change in average: 10.52, 13.22, 14.49 and
\end{abstract}

Fajar Yulianto

fajar.lapan.rs@gmail.com; fajar.yulianto@lapan.go.id

1 Remote Sensing Application Center, Indonesian National Institute of Aeronautics and Space (LAPAN), Jl. Kalisari No. 8, Pekayon, Pasar Rebo, Jakarta 13710, Indonesia

2 Environmental Agency of Riau Islands Province (BLH), Government Office Complex-Riau Island Province, Building C, 3rd Floor, Dompak Island, Tanjungpinang, Indonesia
$1.15 \mathrm{ha} /$ year, respectively. Meanwhile, the area-class bare soil, plantation, settlement and water body would be expected to experience an area increases, with the rate of change in average: $6.79,11.14,11.49$ and 9.7 ha/year, respectively. Furthermore, flood damage assessment can be calculated by estimating LULC area affected by the flood, which is determined based on the overlay between LULC maps from the result of Markov-CA with flood maps from the result of Monte Carlo algorithm. Under current conditions, estimated flood damage exposure to extreme flood events with return periods of 100 years for the water level scenario $\mathrm{Hc}=3 \mathrm{~m}$ and $\mathrm{Hc}=5 \mathrm{~m}$ is more than $€ 520$ and $€ 958$ million, respectively.

Keywords Remote sensing - Flood damage assessment . Tondano watershed $\cdot$ North Sulawesi $\cdot$ Indonesia

\section{Introduction}

Land use/land cover (LULC) can be defined as part of the physical composition and characteristics of the land elements on the earth's surface. LULC systems have complex dynamics, which consists of natural, social and economic spatially. The availability and distribution of LULC change have significant impacts on climate, environmental issue and natural ecosystem conditions (Cihlar 2000; Wang et al. 2012; Yan et al. 2015). The management and good planning to LULC can provide an important role in the moderation of extreme events, climate change mitigation and land degradation. For example, its role can mitigate flood events, landslide and erosion trough water retention in soils and water uptake by vegetation (Stürck et al. 2015). The LULC changes can be caused by several factors, such as human activities, e.g., urbanization, deforestation, 
agriculture intensification and others. In addition, natural factors also contributed to the change of LULC (Lambin 1997; Halmy et al. 2015).

The dynamics of LULC change can be monitored by using remotely sensed data. The availability of remotely sensed data have been provided a variety of temporal, spectral and spatial resolution, which can be used to detect changes on the earth's surface (Rogan and Chen 2004; Wu et al. 2006; Halmy et al. 2015). Furthermore, the utilizations of remotely sensed data were used as input in generating a LULC map. The monitoring of the LULC change dynamics can be done by comparing a LULC map at currently with the conditions in previous years as a multitemporal (Behera et al. 2012). The use of remotely sensed data for mapping of the dynamics of LULC changes has been used extensively. Example include the use of Landsat MSS, Landsat TM, Landsat ETM+, Indian Remote sensing Satellite LISS-III (IRS), MODIS, NOAA/AVHRR, CBERS, among others (e.g., Sun et al. 2007; Gong et al. 2015; Wehmann and Liu 2015; Shooshtari and Gholamalifard 2015; Nejadi et al. 2012; Pouliot et al. 2014; Chen et al. 2013; Yang et al. 2011).
To determine the condition of the LULC in the next several years can be done with modeling of LULC predictions. The modeling can be done either by the model of Markov-CA (Guan et al. 2011; Yang et al. 2014; Gong et al. 2015). The use of Markov-CA is an interesting approach and it has advantages in the modeling of LULC change, spatially and temporally (Sylvertown et al. 1992; Wang and Zhang 2001; Behera et al. 2012). One of the implications of the use of monitoring the dynamics of LULC change and predictions can be used for the flood damage assessment (e.g., Marfai and King 2007; Ward et al. 2010; 2011; Joling 2013; Yulianto et al. 2015a). The flood damage assessment is required to estimate the impact of LULC in the next several years from the occurrence of floods. The existence of such information can then be used as input for flood risk mapping in a region ( $\mathrm{Su}$ et al. 2005; Metzler 2011). Several other studies related to the implications of LULC for the flood damage assessment (e.g., Jonge et al. 1996; Herath 2003; Yen and Anh 2010; Jongman et al. 2012; Beckers et al. 2013).

The city of Manado is a downstream area of the Tondano watershed, and Fig. 1 shown the location of the

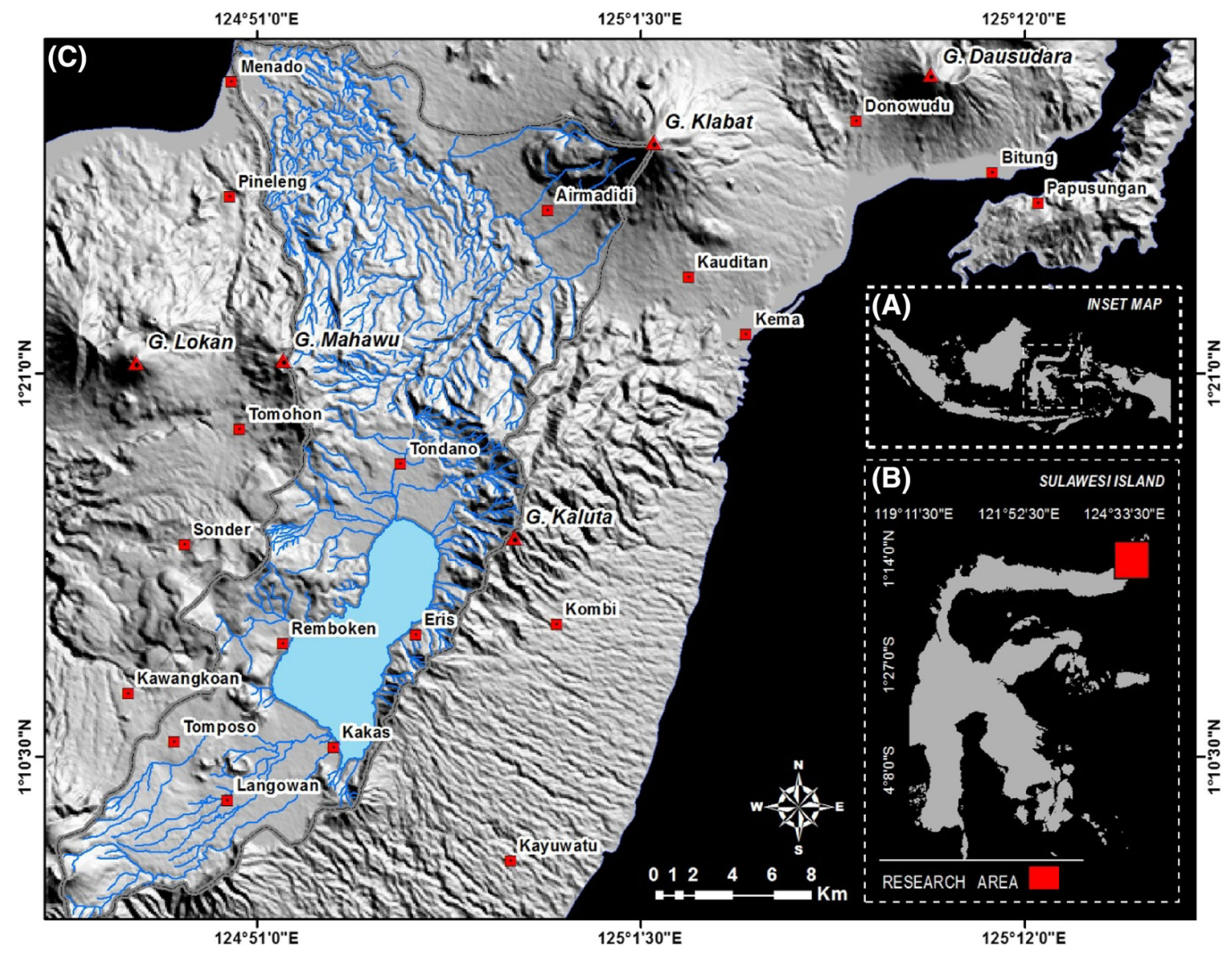

Fig. 1 a Indonesia map for inset location of Sulawesi island. b Inset location of the research area at North Sulawesi. c Digital elevation model (DEM) in the Tondano watershed, North Sulawesi, Indonesia (Source: ASTER GDEM in the year 2011) 
research area. There are four major flood events in the city of Manado based on the historical record, namely: December 3, 2000; February 21, 2006; February 17, 2013 and January 15, 2014 (Dayantolis and Fitri 2014). Flooding that occurred on January 15, 2014 in the city of Manado, North Sulawesi, Indonesia is a flood of greatest impact. Rainfall with an intensity of more than $175 \mathrm{~mm}$ has become one of the causes of flooding in the research area. This condition during the flood event on January 15, 2014 can be shown based on the monitoring of rainfall accumulation from QMorph remotely sensed data on January 13-16, 2014 (Fig. 2). The existence of these conditions for

January 13, 2014 (Time: 00 - 23 UTC)

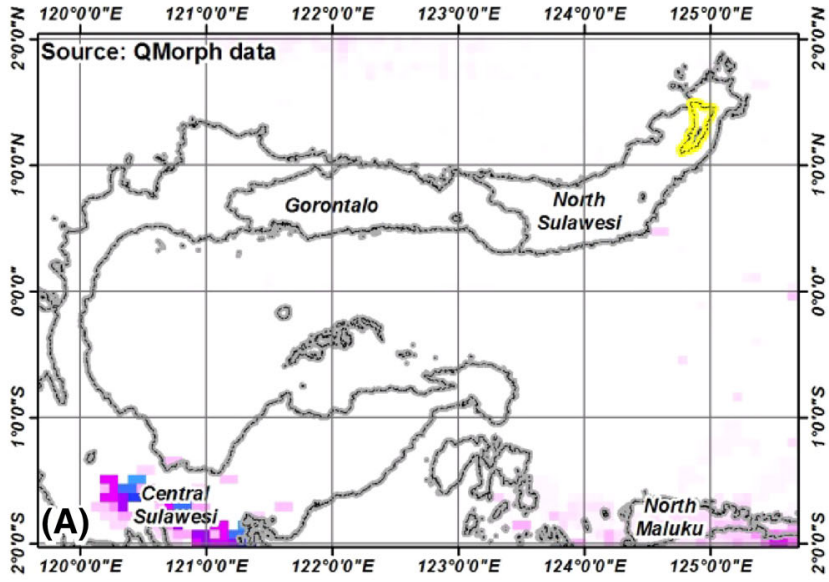

January 15, 2014 (Time: 00 - 23 UTC)
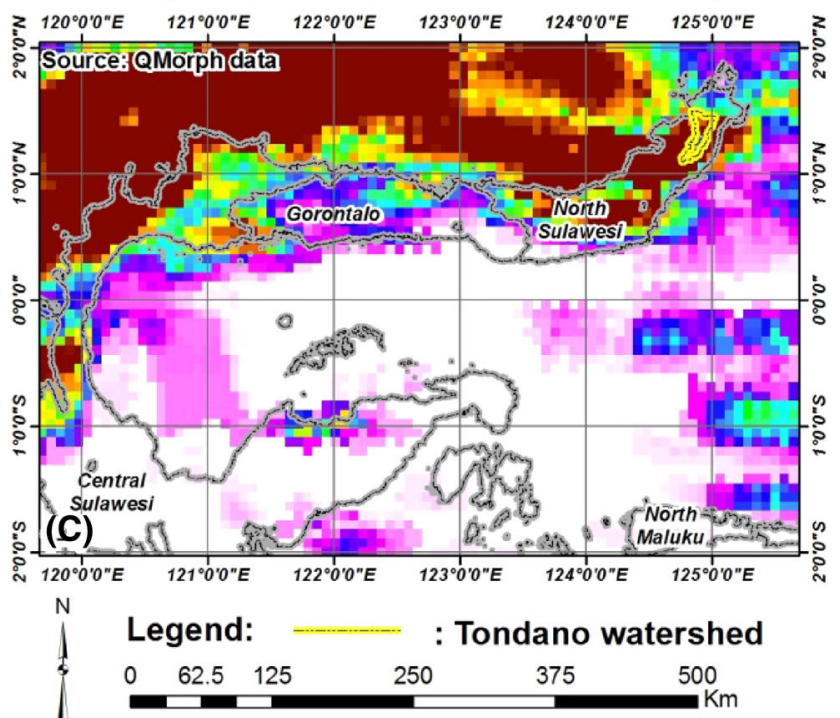

Fig. 2 Rainfall accumulation based on the QMorph remotely sensed data in the research area (Tondano watershed), on January 13-16, 2014. a Rainfall accumulation on January 13, 2014, time: 00-23 UTC. b Rainfall accumulation on January 14, 2014, time: 00-23
2 days with a relatively long duration of time has triggered flood in the research area.

The availability of information related to the impact of flood events in the research area is important to be done with the aim to quickly estimate of losses caused by flooding. One of the immediate measures that can be used to calculate the impact of flooding on LULC. In addition, the calculation of the impact of flooding from LULC change needs to be done in order to determine the potential loss to the effects of flooding in the future. That information can be used as input to government and several stakeholders to anticipate and minimize the impact of flood

\section{January 14, 2014 (Time: 00 - 23 UTC)}

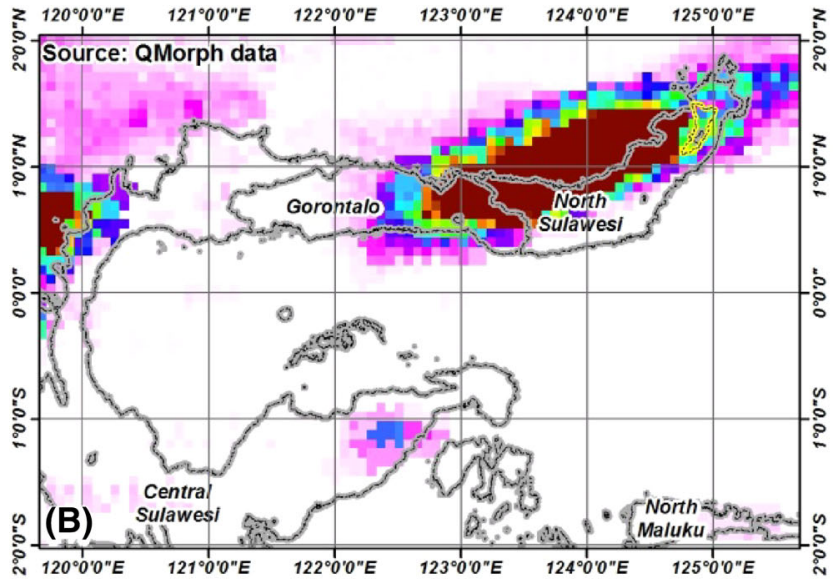

January 16, 2014 (Time: 00 - 23 UTC)

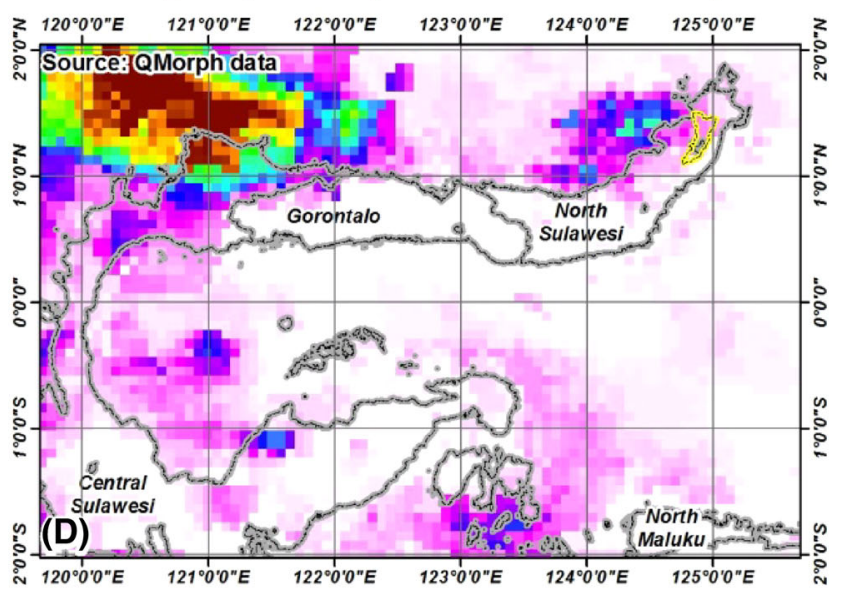

\section{Rainfall (mm)}

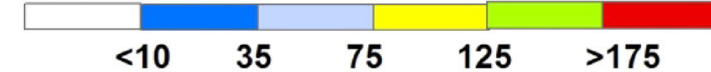

UTC. c Rainfall accumulation on January 15, 2014, time: 00-23 UTC. d Rainfall accumulation on January 16, 2014, time: 00-23 UTC (Source: QMorph remotely sensed data, processed by: LAPAN 2014) 
risk and it can also be used as a reference in environmental management policies in the research area. The objectives of this research are: (a) to analyze, modeling and predictions the dynamics of LULC change from multi-temporal remotely sensed data, (b) to implement the results of modeling the dynamics of LULC change and predictions for the flood assessment in the research area.

Table 1 The number of the population living at the Tondano watershed in the year 2014

\begin{tabular}{|c|c|}
\hline Districts & Number of population in 2014 \\
\hline \multicolumn{2}{|l|}{ Manado } \\
\hline Mapanget & 51,259 \\
\hline Paal Dua & 42,798 \\
\hline Singkil & 47,963 \\
\hline Tikala & 29,136 \\
\hline Tuminting & 51,039 \\
\hline Wanea & 22,768 \\
\hline Wenang & 33,048 \\
\hline \multicolumn{2}{|l|}{ Minahasa } \\
\hline Langowan Timur & 12,475 \\
\hline Langowan Barat & 15,308 \\
\hline Langowan Selatan & 7539 \\
\hline Langowan Utara & 8158 \\
\hline Tompaso & 16,117 \\
\hline Kawangkoan & 26,578 \\
\hline Sonder & 18,064 \\
\hline Tombulu & 16,196 \\
\hline Tondano Barat & 19,513 \\
\hline Tondano Selatan & 21,815 \\
\hline Remboken & 11,175 \\
\hline Kakas & 21,473 \\
\hline Eris & 9819 \\
\hline Kombi & 9874 \\
\hline Tondano Timur & 14,130 \\
\hline Tondano Utara & 12,525 \\
\hline \multicolumn{2}{|l|}{ Minahasa Utara } \\
\hline Kauditan & 24,263 \\
\hline Airmadidi & 28,153 \\
\hline Kalawat & 29,743 \\
\hline Dimembe & 23,568 \\
\hline Talawaan & 19,932 \\
\hline \multicolumn{2}{|l|}{ Tomohon } \\
\hline Tomohon Selatan & 21,682 \\
\hline Tomohon Tengah & 21,329 \\
\hline Tomohon Timur & 10,453 \\
\hline Total & 697,893 \\
\hline
\end{tabular}

Source: Indonesian of Central Agency Statistics (BPS) 2014a, b, c, d

\section{Study area}

The Tondano watershed in North Sulawesi, Indonesia, is located at the coordinates of about at $1^{\circ} 27^{\prime} 18.72^{\prime \prime}$ to $1^{\circ} 6^{\prime} 8.28^{\prime \prime} \mathrm{N}$ and $125^{\circ} 1^{\prime} 38.64^{\prime \prime}$ to $124^{\circ} 45^{\prime} 57.24^{\prime \prime} \mathrm{E}$, and It is an include some district or city. For the upstream areas, the coverage area is an includes most of the Minahasa district, Minahasa Utara district and Tomohon city. Meanwhile, for the downstream areas, the coverage area is an includes most of the Manado city. The Tondano watershed area is about 54,108 Ha, which is divided into four (4) sub-watershed, namely: Tikala, Klabat, Tondano and Noongan (The Management Center of Tondano Watershed-Ministry of Forestry 2014). The number of people living in the Tondano watershed area for the year 2014 was more than 697,893 people and distributed in several districts. Table 1 shown the number of the population living in the Tondano watershed for the year 2014 (Indonesian of Central Agency Statistics (BPS) 2014a, b, c, d).

The geological conditions in North Sulawesi is dominated by limestone sedimentary basin as a unit Raratotok. Other rock types are breccias and sandstones, which consists of rough breccia-conglomerate, interspersed with smooth up rough sandstones, silt stone and clay stone, as well as pyroxene andesite breccia. The group of tuff Tondano has a Pliocene age and consists of fragments of andesitic volcanic rocks that contain pumice, tuff and ignimbrite breccia and andesite lava. In the Quaternary rocks are a group of young volcanic rocks, consisting of andesite-basalt lava, bombs, lapilli and ash. Meanwhile, the youngest rock group has a composition of limestone coral reefs, lakes and rivers and sediment deposition alluvium (Sompotan 2012). Figure 3 shown the geological conditions of the research area, which is part of Sulawesi island, Indonesia.

\section{Method}

\section{Data availability}

The availabilities of satellite image data were used in this research consists of Landsat $5 \mathrm{TM}$, Landsat $7 \mathrm{TM}$, Landsat 8 LDCM and ASTER GDEM, which have a spatial resolution of $30 \mathrm{~m}$. Multi-temporal Landsat image data were used as input for LULC mapping, modeling and prediction of the dynamic LULC change. Meanwhile, the availability of ASTER GDEM data was used as input for flood modeling in the research area. Table 2 shown the availability of satellite image data were used in this research. 


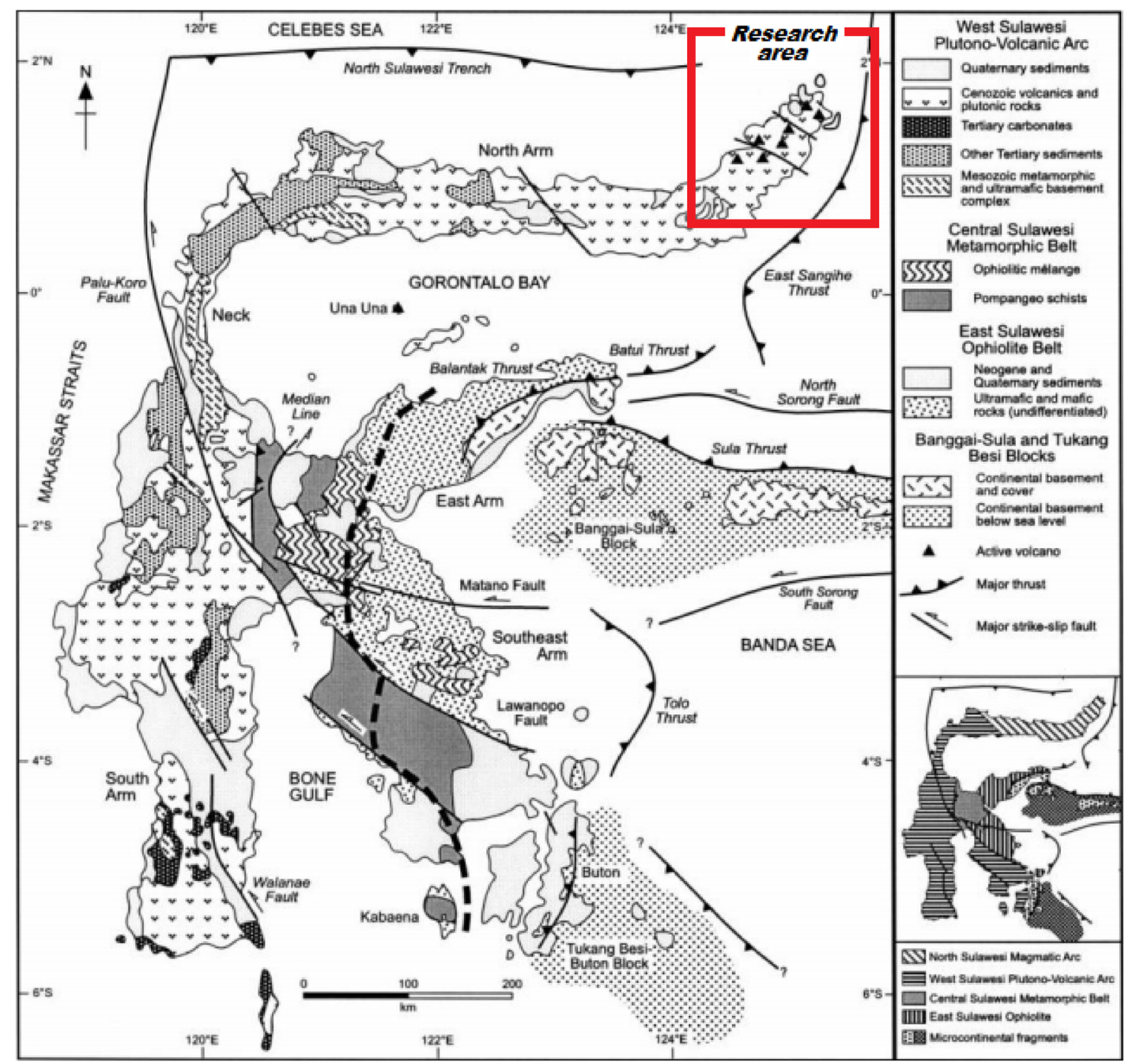

Fig. 3 Geological map of Sulawesi, Indonesia (Source: Hall and Wilson 2000; Sompotan 2012)

Table 2 The availability of satellite image data were used in this research

\begin{tabular}{lllll}
\hline Date type & Spatial resolution $(\mathrm{m})$ & Path and row & Acquisition date & Source \\
\hline Landsat 5 TM & 30 & 112,059 & June 04, 1997 & USGS \\
Landsat 7 TM & 30 & 112,059 & May 25, 2002 & USGS \\
Landsat 7 TM & 30 & 112,059 & July 28, 2002 & USGS \\
Landsat 8 LDCM & 30 & 112,059 & January 29, 2015 & LAPAN \\
Landsat 8 LDCM & 30 & 112,059 & April 03, 2015 & LAPAN \\
Landsat 8 LDCM & 30 & 112,059 & May 21, 2015 & LAPAN \\
ASTER GDEM & 30 & N01, E124 & October 17, 2011 & Japan space systems
\end{tabular}




\section{Data processing and analysis}

\section{Pre-processing satellite images}

The pre-processing stages in this research were conducted by converting the value of Digital Number (DNs) into the reflectance values of Top of Atmosphere. In the standard product Landsat $5 \mathrm{TM}$ and Landsat $7 \mathrm{TM}$ imagery have DNs format 8-bit unsigned integer. Meanwhile, the standard product of Landsat 8 LDCM imagery has DNs format 16-bit unsigned integer. The pre-processing stage is done with the purpose to obtain the standard reflectance values, because there are differences in the DNs format of the image data. Thus, the results of the pre-processing data can be used for processing and analysis in the later stages. Landsat data processing in this research was done using the Semi-Automatic Classification Plugin contained on Open Source software Quantum GIS (QGIS) 2.12.2 Lyon and it was released on December 18, 2015 (http://www.qgis.org/ en/site/forusers/download.html). According to Luca et al. (2013), this plugin is a free plugin for QGIS and it can be used for the semi-automatic supervised classification designed to expedite the processing of multispectral or hyperspectral remote sensing images, which provides a set of tools for pre-processing and post-processing.

In the pre-processing stage was required to change the range of values DNs in the image into reflectance values or radians using radiometric coefficients from the metadata file (MTL_file). The conversion process of DNs values into the reflectance values consists of two stages. The first stage is to convert the DNs values into radian values, and the second stage is to convert the radian values into the reflectance values. Formula to convert DNs values into radian values can be presented in Eq. (1). Meanwhile, the formula to convert the radian value into the reflectance values can be presented in Eq. (2) (Chavez 1988; NASA 2011; Luca et al. 2013; USGS 2013a, b).

$L \lambda=\left(\frac{\left(\operatorname{LMAX}_{\lambda}-\operatorname{LMIN}_{\lambda}\right)}{\left(Q_{\text {Calmax }}-Q_{\text {Calmin }}\right)}\right) \times\left(Q_{\text {Cal }}-Q_{\text {Calmin }}\right)+L M I N_{\lambda}$

where $L \lambda$ is the spectral radiance at the sensor's aperture. $Q_{\text {Cal }}$ is the quantized calibrated pixel value. $L M I N_{\lambda}$ is the spectral radiance that is scaled to $Q_{\text {Calmin }} . L M A X_{\lambda}$ is the spectral radiance that is scaled to $Q_{\text {Calmax }} . Q_{\text {Calmin }}$ is the minimum quantized calibrated pixel value. $Q_{\text {Calmax }}$ is the maximum quantized calibrated pixel value.

$\rho=\left[\pi \times\left(L_{\lambda}-L_{\rho}\right) \times d^{2}\right] /\left(E S U N_{\lambda} \times \cos \theta_{s}\right)$

where $\rho$ is the land surface reflectance for Landsat images. $L_{\lambda}$ is the at satellite radiance. $L_{\rho}$ is the path radiance. $d$ is the earth to sun distance in astronomical units. $E S U N_{\lambda}$ is the mean solar Exo-atmospheric irradiances. $\theta_{s}$ is the solar zenith angle.

\section{The classification process for Land use/land cover mapping}

At this stage, the multi-temporal of Landsat imagery were used as input for processing and classification of LULC mapping. The processing is done by the individual training areas. The maximum likelihood (ML) was used as a classification algorithm on the semi-automatic classification plugin, which is part of the supervised classifier categories.

According to Richards and Jia (2006), Huang et al. (2009), and Luca et al. (2013), the ML algorithm is used the Gaussian threshold stored in each class signature to assign every pixel class, which assumed that the probability distribution for the classes of the models form of multivariate normal. ML algorithm can be presented in Eqs. (3) and (4).

$G_{i}(\mathrm{x})=\ln \mathrm{p}\left(\omega_{i}\right)-\frac{1}{2} \ln \left|\sum_{i}\right|-\frac{1}{2}\left(\mathrm{x}-m_{i}\right)^{\mathrm{t}} \sum_{i}^{-1}\left(x-m_{i}\right)$

Therefore:

$\mathrm{x} \in \omega_{i} \mathrm{i} \quad$ if $g_{i}(\mathrm{x})>g_{j}(\mathrm{x})$ for all $\mathrm{j} \neq \mathrm{I}$

where $G_{i}(\mathrm{x})$ is the discriminant function in ML algorithm. $\omega_{i}$ is the class, where $i=1, \ldots, \mathrm{M}$ and $\mathrm{M}$ is the total number of classes. $x$ is the vector pixel in $n$-dimensional, where $n$ is the number of bands. $\mathrm{p}\left(\omega_{i}\right)$ is the probability that the correct class, in $\omega_{i}$ for a pixel at position $x .\left|\sum_{i}\right|$ is the determinant of the covariance matrix of the data in class $\omega_{i} . \sum i$ is the inverse of the covariance matrix. $m_{i}$ is the mean vector.

\section{Modeling and prediction of the dynamic land use/land cover change}

In this research, modeling and prediction of the dynamic LULC change has been carried out by using a Markov-CA. LULC maps in 1997 and 2002, which is the results of multi-temporal classification of Landsat imagery, were used as input data for the modeling and prediction LULC in the next years. Meanwhile, LULC map in 2015 that is the classification result of Landsat imagery in 2015 was used as a reference map to describe the condition LULC today. The reference of LULC map was used to perform the calculation of the accuracy assessment LULC in 2015 with Markov-CA approach.

Markov-CA approach is a combination model of Markov Chain and Cellular Automata approach, which can be used to predict and simulate LULC change in several next year (Behera et al. 2012; Yang et al. 2014). The Markov 
Chain model is a stochastic process model that can describe the probability of a change from one object to another. The model is one of the recommended methods for modeling LULC based on the use of the time evolutionary trend. It means that the time $(t-1)$ to time $(t)$ can be used as input probability LULC change, which is further used for LULC prediction in the next year $(\mathrm{t}+1)$ (Thomas and Laurence 2006; Behera et al. 2012). Cellular Automata is a part of the essential elements of geo-spatial, which focus on the variations in the dynamics of change and it is able to simulate the characteristics of the spatial-temporal complex system and it cannot be represented by a specific

Table 3 The parameter data were used for simulation of the probability of flood inundation using a Monte Carlo algorithm in the upper boundary Tondano river

\begin{tabular}{llllll}
\hline $\begin{array}{l}\text { Return periods } \\
\text { (years) }\end{array}$ & $\begin{array}{l}\text { Volume } \\
\left(\mathrm{m}^{3}\right)\end{array}$ & $\begin{array}{l}\text { Maximum flow } \\
\text { length }(\mathrm{m})\end{array}$ & $\begin{array}{l}\text { Start iteration position } \\
(\mathrm{X} ; \mathrm{Y})\end{array}$ & $\begin{array}{l}\text { Height correction for water level } \\
(\mathrm{Hc})\end{array}$ & \begin{tabular}{l} 
The number of iterations \\
\cline { 3 - 5 }
\end{tabular} \\
\hline 2 & $91,411,390$ & 7435 & $711593 ; 163768$ & $3 \mathrm{~m}, 5 \mathrm{~m}$ & $3 \mathrm{~m}$ \\
5 & $107,900,660$ & 7435 & $711593 ; 163768$ & $3 \mathrm{~m}, 5 \mathrm{~m}$ & 20,300 \\
10 & $120,547,770$ & 7435 & $711593 ; 163768$ & $3 \mathrm{~m}, 5 \mathrm{~m}$ & 24,000 \\
20 & $133,995,330$ & 7435 & $711593 ; 163768$ & $3 \mathrm{~m}, 5 \mathrm{~m}$ & 44,000 \\
50 & $153,526,310$ & 7435 & $711593 ; 163768$ & $3 \mathrm{~m}, 5 \mathrm{~m}$ & 49,600 \\
100 & $169,695,400$ & 7435 & $711593 ; 163768$ & $3 \mathrm{~m}, 5 \mathrm{~m}$ & 33,700 \\
\hline
\end{tabular}

Source: summarized and modified data from Nanlohy et al. 2008
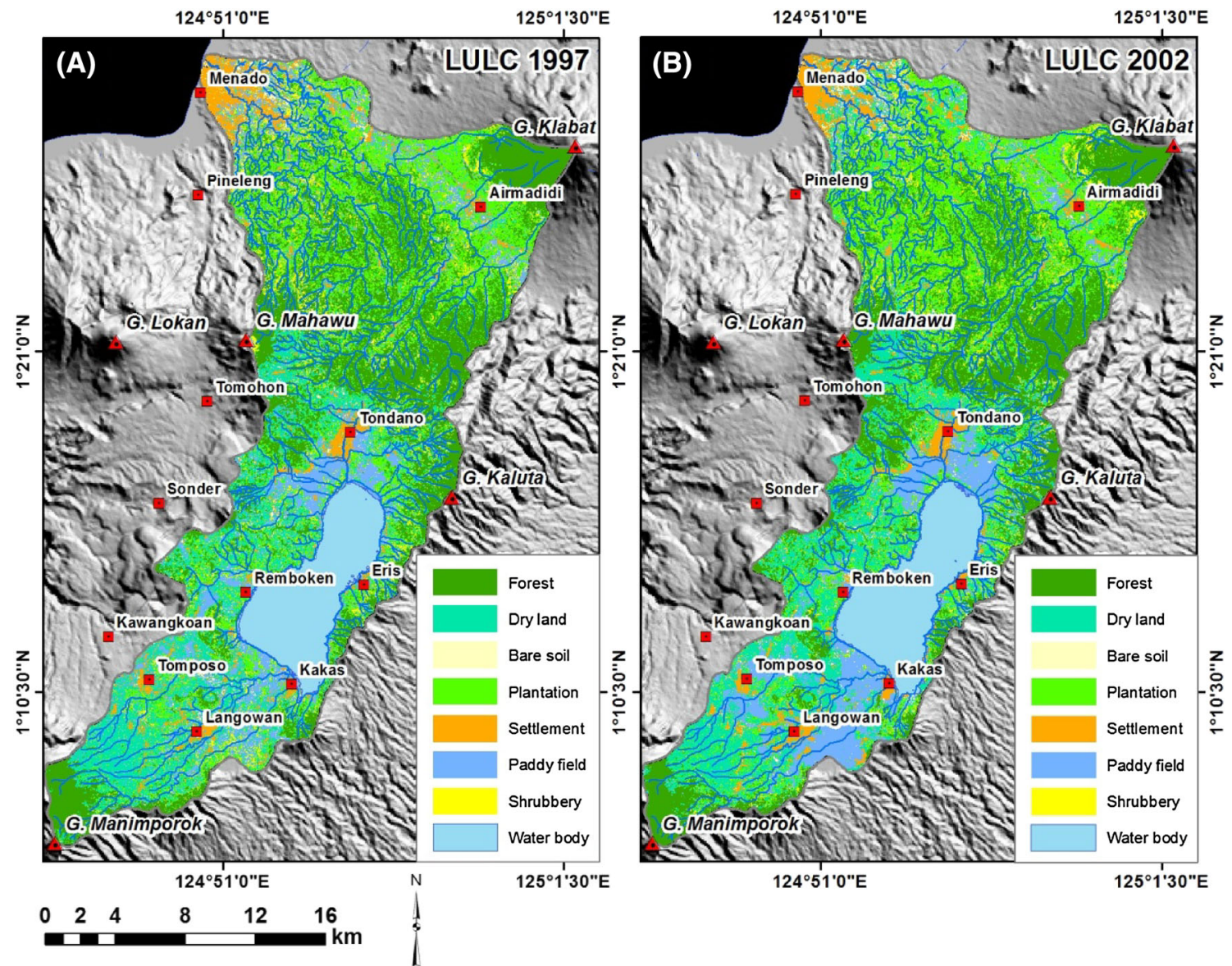

Fig. 4 The results of LULC map using maximum likelihood supervised classification on Landsat imagery. a LULC in the year 1997. b LULC in the year 2002 

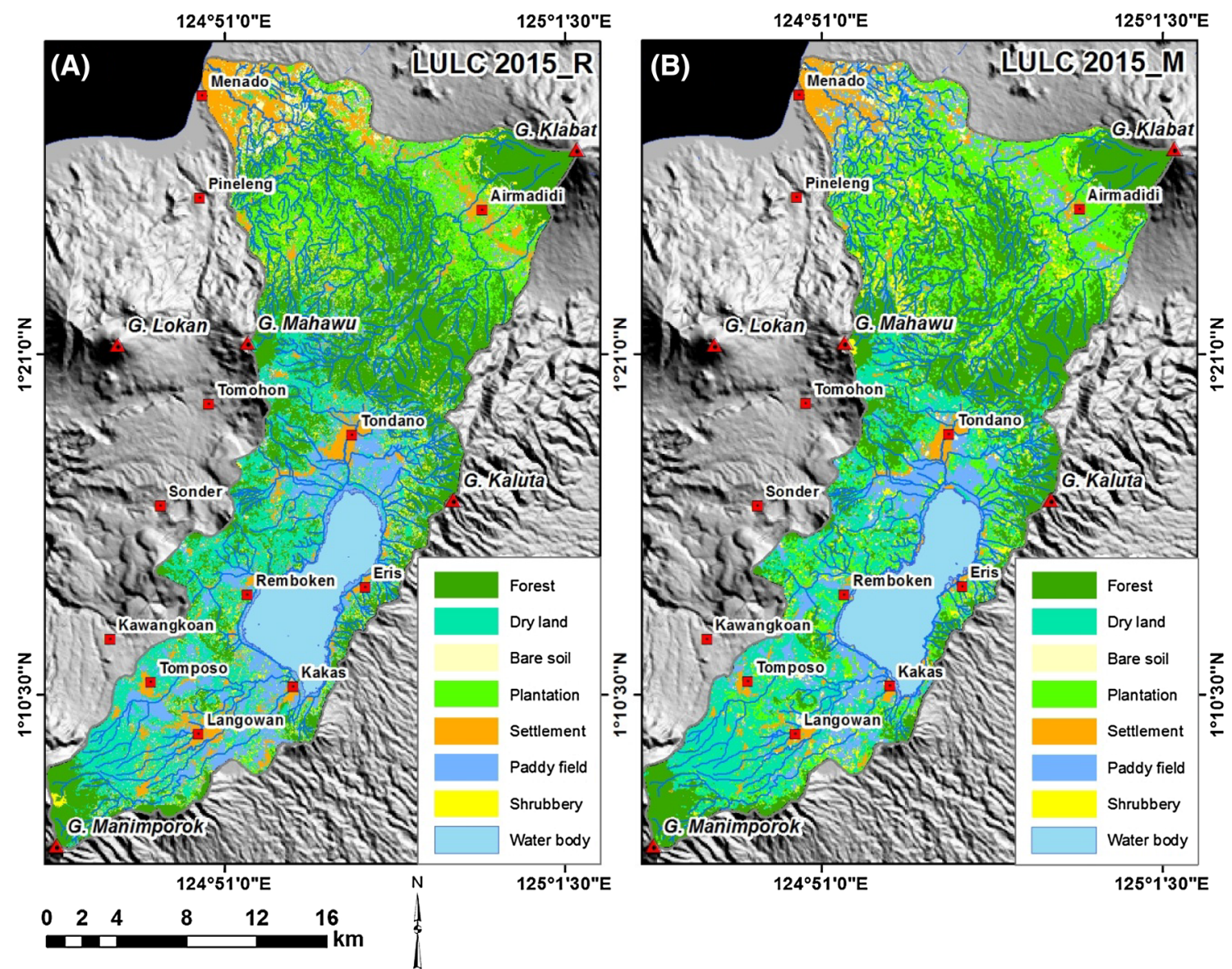

Fig. 5 Comparison between LULC classification was used as a reference map, with the LULC class was generated from the modeling MarkovCA approach. a LULC map in the year 2015 (reference map). b LULC map in the year 2015 (model map)

Table 4 The estimate area of LULC changes for the year $1997-2015$ in the research area

\begin{tabular}{lccc}
\hline LULC Class & \multicolumn{3}{l}{ Year } \\
\cline { 2 - 4 } & 1997 & 2002 & 2015 \\
& Area (ha) $^{\mathrm{a}}$ & Area (ha) $^{\mathrm{a}}$ & Area (ha) $^{\mathrm{a}}$ \\
\hline Forest & $16,498.44(29.20)$ & $15,617.37(27.64)$ & $14,305.65(25.32)$ \\
Dry land & $9390.15(16.62)$ & $10,181.44(18.02)$ & $10,596.88(18.76)$ \\
Bare soil & $587.61(1.04)$ & $810.01(1.43)$ & $946.36(1.67)$ \\
Plantation & $12,487.05(22.10)$ & $13,309.27(23.56)$ & $13,591.90(24.06)$ \\
Settlement & $2811.42(4.98)$ & $3270.47(5.79)$ & $3957.39(7.00)$ \\
Paddy fields & $6660.54(11.79)$ & $5095.80(9.02)$ & $4714.21(8.34)$ \\
Shrubbery & $3651.84(6.46)$ & $3721.96(6.59)$ & $3836.89(6.69)$ \\
Water body & $4413.96(7.81)$ & $4494.69(7.96)$ & $4551.74(8.06)$ \\
Total & $56,501.01(100)$ & $56,501.01(100)$ & $56,501.01(100)$ \\
\hline
\end{tabular}

a Percentage area equation (Mousivand et al. 2007; Arsanjani et al. 2013; Yang et al. 2014). In this research, the modeling LULC have been processed by the tools of Markov-CA module contained in the IDRISI Andes software, which is developed by Clark Labs at Clark University.

\section{Implication for the flood damage assessment}

Their implication for flood damage assessment in the research area has been carried out by calculating the impact of flooding inundation of the LULC, which can scripted 
Table 5 The estimate of the average rate area of LULC changes for the year 1997-2015 in the research area

\begin{tabular}{lccc}
\hline LULC class & Change area (ha) & Average area (ha/year) \\
\cline { 2 - 3 } & $1997-2002$ & $2002-2015$ & $1991-2015$ \\
\hline Forest & -881.07 & -1311.73 & -121.82 \\
Dry land & +791.29 & +415.44 & +67.04 \\
Bare soil & +222.40 & +136.35 & +19.93 \\
Plantation & +822.22 & +282.63 & +61.38 \\
Settlement & +459.05 & +686.93 & +63.67 \\
Paddy fields & -1564.74 & -381.60 & -108.13 \\
Shrubbery & +70.12 & +114.93 & +10.28 \\
Water body & +80.73 & +57.05 & +7.65 \\
\hline
\end{tabular}

'-' decrease; '+' increase

Table 6 The accuracy of the Kappa index for the LULC map in 2015, which is the result of the maximum likelihood supervised classification and corrected by using high-resolution imagery from Google Earth

\begin{tabular}{|c|c|c|c|c|c|c|c|c|c|}
\hline \multirow[t]{2}{*}{ LULC Classes } & \multicolumn{8}{|c|}{ Reference } & \multirow[t]{2}{*}{ Total } \\
\hline & Forest & Dry land & Bare soil & Plantation & Settlement & Paddy fields & Shrubbery & Water body & \\
\hline Forest & 151 & 3 & - & 16 & - & - & - & - & 170 \\
\hline Dry land & - & 70 & - & 2 & - & 11 & 1 & - & 84 \\
\hline Bare soil & 1 & 0 & 6 & 1 & 2 & 1 & 2 & 1 & 14 \\
\hline Plantation & 3 & 1 & 1 & 55 & 1 & 4 & 1 & - & 66 \\
\hline Settlement & - & - & - & 1 & 49 & - & - & - & 50 \\
\hline Paddy fields & - & 8 & 2 & 7 & 1 & 62 & 4 & 1 & 85 \\
\hline Shrubbery & 4 & 1 & 3 & 2 & - & 4 & 26 & - & 40 \\
\hline Water body & - & - & - & - & - & - & - & 39 & 39 \\
\hline Total & 159 & 83 & 12 & 84 & 53 & 82 & 34 & 41 & 548 \\
\hline
\end{tabular}

and predictable for the next few years. In this research, flood inundation scenarios have been created by the Monte Carlo algorithm approach. Flood inundation modeling with the Monte Carlo algorithm approach does not require complex parameters and does not require long processing times, as it has been applied to some previous studies (e.g., Smemoe et al. 2007; Kalyanapu 2011; Yulianto et al. 2015b). The use of Monte Carlo algorithms previously were conducted by Felpeto et al. (2007) and Felpeto (2009) to simulate an inundation on the lava flows. The algorithm model is a probabilistic model, with the assumption that the topographic conditions have a dominant factor for determining the material flows.

In this research, topographic data can be represented by ASTER GDEM, with a spatial resolution of $30 \mathrm{~m}$. In addition, several other parameters were used to run the Monte Carlo algorithm, e.g., maximum flow length, location to start iteration, height correction for water level scenario and the number of iterations. Table 3 shown the parameter data were used for simulation of the flood probability using a Monte Carlo algorithm in the upper boundary Tondano river. The probability of flood inundation using a Monte Carlo algorithm can be presented in Eqs. (5)-(7) (Felpeto 2009; Yulianto et al. 2015b).

$P_{i}=\frac{\Delta h_{i}}{\sum_{j=1}^{8} \Delta h_{j}}$

$\Delta h_{i}=h_{0}+h_{c}-h_{i} \quad$ if $\left(h_{0}+h_{c}-h_{i}\right)>0$

$\Delta h_{i}=0 \quad$ if $\left(h_{0}+h_{c}-h_{i}\right) \leq 0$

where $P_{i}$ is the probability of material flows. $h_{i}$ is the topography represented by the value of the height $(h)$ of a cell in the DEM data located in the cells $i=0$ and $i=$ $1,2,3, \ldots, 8) . \Delta h$ is the height difference between the cell with a cell-neighboring. $h_{c}$ is the height correction.

The numbers of iteration were determined by the approximation formula. The formula was developed by Zhu (2010) and it has been applied by Seniarwan and 
Gandasasmita (2013) and Yulianto et al. (2015b) to simulate the inundation models. This formula can be presented in Eqs. (8) and (9).

$f(H)=Q-V=Q-\sum_{i=1}^{m} A x(H i-E i)$

$V=\sum_{i=1}^{m} A x h c$

where $f(H)$ is the function of the equation to analyze the flood inundations height $(H)$, which is based on the ratio between the volume grooves topography $(V)$ and the volume of the flood source $(Q) . H_{i}$ is the accumulation of flood inundation height between the $h_{c}$ and the DEM elevation $E_{i}$ in unit pixels $i$ and $i=(1,2,3, \ldots, n) . m$ is the number of units pixels or pixel iterations required. $A$ is the area of the unit pixels.

The flood damage assessment can be created using overlaying the maps of flood inundation model under scenario return periods: $2,5,10,20,50$ and 100 years with the maps of LULC modeling under scenario for the 2015, 2025, 2035 and 2050 years. Based on the results of the overlay can be estimated LULC affected by floods for several next year. The value of assets has been calculated with reference to the research conducted by Marfai and King (2007) and Ward et al. (2011) and we have the same assumptions for asset values in the research area with the Semarang and Jakarta, Indonesia.

The value of assets for settlement was estimated to be ca. $€ 1.2$ million per hectare, for agriculture (e.g., paddy field, dry land and plantation) was estimated to be ca. $€ 80,000$ per hectare, and also for open area (e.g., bare soil and shrubbery) was estimated to be ca. $€ 1700$ per hectare. The absolute value of exposure damage estimated in this research are considered as an indication. Exposure damage was estimated based on the actual market value per hectare in each class LULC. However, these estimates give a good impression of exposure damage on LULC changes due to flooding.

\section{Results}

\section{Land use/land cover mapping in the research area}

In this research, the dynamics LULC change can be described using LULC maps in the year 1997, 2002 and 2015, which is the result of the maximum likelihood classification of Landsat imagery. Spatially, the dynamics LULC change from the year 1997 to 2015 can be presented in Figs. 4 and 5a. Meanwhile, the estimate area for LULC changes in the year 1997 to 2015 can be presented in
Fig. 6 LULC maps from the modeling using Markov-CA approach. a LULC map prediction for the year 2025. b LULC map prediction for the year 2035. c LULC map prediction for the year 2050

Tables 4 and 5. It can be shown that for LULC class on forest and paddy fields have experienced a decrease in the extent of 1997-2015, with an average change of area: 121.82 and 108.13 ha/year, respectively. Meanwhile, LULC class on dry land, bare soil, plantation, settlement, shrubbery and water body have experienced an increase with an average change of area: 67.04, 19.93, 61.38, 63.67, 10.28 and $7.65 \mathrm{ha} /$ year, respectively.

\section{Modeling and prediction of the dynamic land use and land cover change}

Modeling and prediction of the dynamic LULC change have been created with Markov-CA approach. LULC maps in the year 1997 and 2002 were used as input data for LULC mapping in the next few years. Meanwhile, LULC map in the year 2015 was used as a reference map to determine the accuracy assessment of LULC model in the year 2015 from Markov-CA approach. The accuracy of the LULC reference in 2015 has been determined based on 548 sample location in the research area. At the sample location, LULC map in 2015 can be corrected by using highresolution imagery from Google Earth. The results of calculation were performed by using the Kappa index obtained accuracy of $80.11 \%$, with the real similarity object of $83.57 \%$ and inequality objects of $16.43 \%$. Table 6 shown the accuracy of the Kappa index on the LULC map in 2015, which is the result of the maximum likelihood supervised classification. Furthermore, the accuracy assessment of the LULC map from Markov-CA approach can be calculated using cross-confusion matrix between LULC reference in 2015 to LULC model in 2015 and it can be shown that the accuracy LULC model of $75.88 \%$. Figure 5 shown the comparison between LULC classification was used as a reference map, with the LULC class was generated from the modeling Markov-CA approach. Meanwhile, the result of the LULC prediction in 2025, 2035 and 2050 can be shown in Fig. 6.

Based on the results of modeling and prediction LULC using Markov-CA approach, the estimate area for LULC changes in the year 2015-2050 can be presented in Tables 7 and 8. It can be shown that for LULC class on the forest, dry land, paddy fields and shrubbery have predicted a decrease in the extent of 2015-2050, with an average change of area: 10.52, 13.22, 14.49 and 1.15 ha/year, respectively. Meanwhile, LULC class on bare soil, plantation, settlement and water body have predicted an 

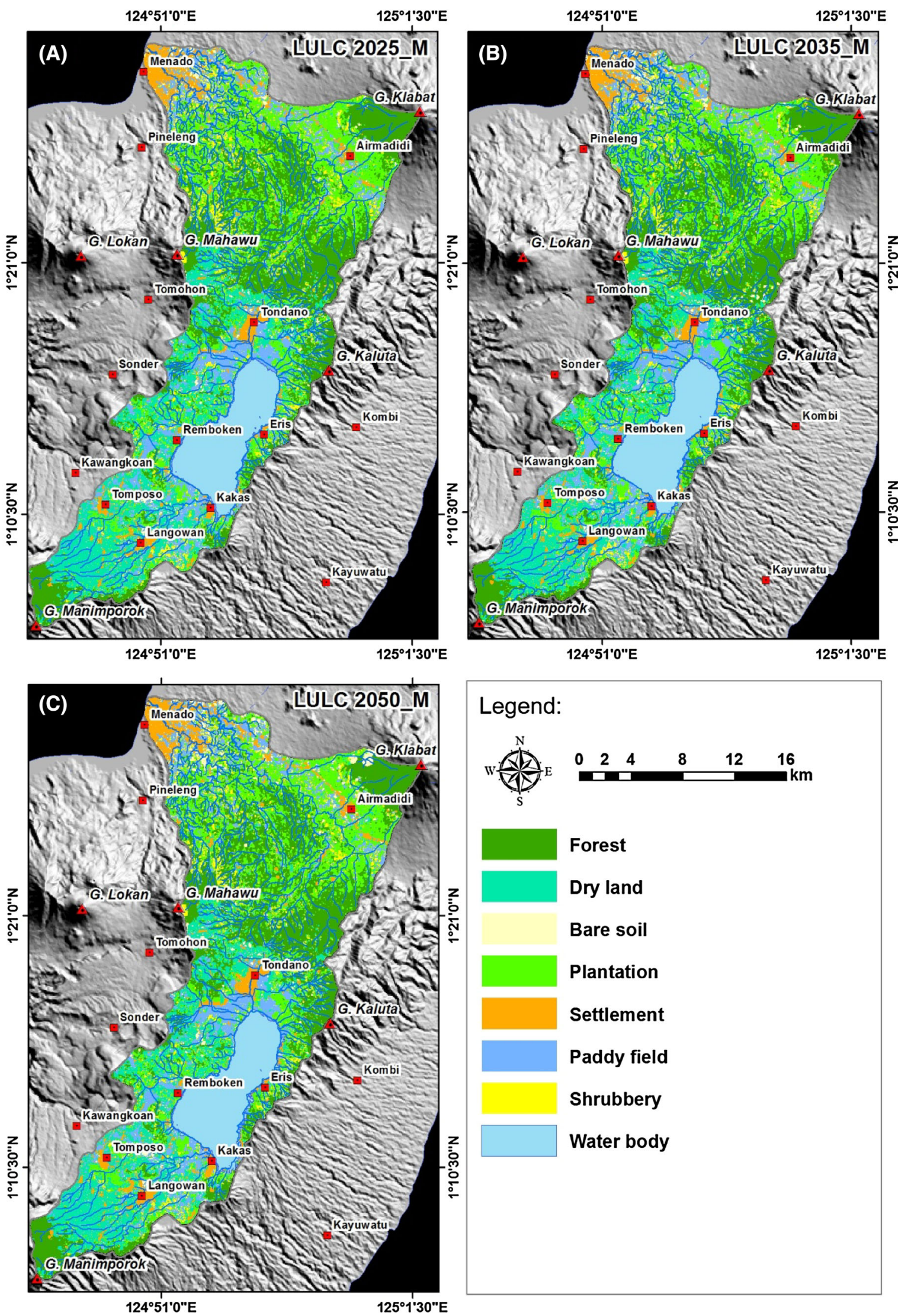
Table 7 The estimate area of LULC changes for the year 2015-2050 in the research area, which is the result of MarkovCA approach

\begin{tabular}{lcccc}
\hline LULC class & Year & & \\
\cline { 2 - 5 } & 2015 & 2025 & 2035 & 2050 \\
& Area (ha) & Area (ha) & Area (ha) \\
& $14150.82(25.05)$ & $14012.89(24.80)$ & $13884.33(24.57)$ & $13782.46(24.39)$ \\
\hline Forest & $9567.41(16.93)$ & $9527.44(16.86)$ & $9432.80(16.69)$ & $9104.78(16.11)$ \\
Dry land & $763.82(1.35)$ & $787.82(1.39)$ & $930.16(1.65)$ & $1025.41(1.81)$ \\
Bare soil & $11461.22(20.28)$ & $11561.19(20.46)$ & $11667.34(20.65)$ & $11851.05(20.97)$ \\
Plantation & $5476.19(9.69)$ & $5546.91(9.82)$ & $5558.26(9.84)$ & $5878.28(10.40)$ \\
Settlement & $7138.69(12.63)$ & $6968.71(12.33)$ & $6842.73(12.11)$ & $6631.38(11.74)$ \\
Paddy fields & $3643.86(6.45)$ & $3615.60(6.40)$ & $3603.49(6.38)$ & $3603.28(6.38)$ \\
Shrubbery & $4275.00(7.57)$ & $4504.47(7.97)$ & $4582.12(8.11)$ & $4624.16(8.18)$ \\
Water body & $56,501.01(100)$ & $56,501.01(100)$ & $56,501.01(100)$ & $56,501.01(100)$ \\
Total & & & &
\end{tabular}

a Percentage area

\begin{tabular}{lcccc}
\hline LULC class & \multicolumn{2}{l}{ Change area (ha) } & \multicolumn{2}{c}{$\begin{array}{l}\text { Average area (ha/year) } \\
\end{array}$} \\
\cline { 2 - 4 } & $2015-2025$ & $2025-2035$ & $2035-2050$ & $2015-2050$ \\
\hline Forest & -137.93 & -128.56 & -101.86 & -10.52 \\
Dry land & -39.97 & -94.64 & -328.02 & -13.22 \\
Bare soil & +24.00 & +166.34 & +95.25 & +6.79 \\
Plantation & +99.96 & +106.15 & +183.71 & +11.14 \\
Settlement & +70.71 & +11.35 & +320.02 & +11.49 \\
Paddy fields & -169.98 & -125.98 & -211.34 & -14.49 \\
Shrubbery & -28.26 & -12.32 & -0.21 & -1.15 \\
Water body & +229.47 & +77.65 & +42.04 & +9.97 \\
\hline
\end{tabular}

'_' decrease; '+' increase
Table 8 The estimate of the average rate area of LULC changes for the year 2015-2050 in the research area, which is the result of Markov-CA approach increase with an average change of area: 6.79, 11.14, 11.49 and 9.7 ha/year, respectively.

\section{Implication for flood damage analysis}

In this research, flood modeling has been performed by the Monte Carlo algorithm approach. Flood modeling scenario was created based on the annual flood for periods, namely: 2 , 5, 10, 20, 50 and 100 years. The water level in the modeling has been created by scenarios $\mathrm{Hc}=3 \mathrm{~m}$ and $\mathrm{Hc}=5 \mathrm{~m}$. Selection of the height flood inundation scenarios has been conducted based on observations of the real flood conditions in the field, which had occurred on January 15, 2014. The results showed that the height of the flood at the time of the incident almost reached the roof of the house settlements, which has a height of $3 \mathrm{~m}$. One of these conditions can be shown in Fig. 7, which is heavily populated locations in Malendeng village. In addition, the height of the flood inundations has also reached about $5 \mathrm{~m}$ at the time of the flood event on January 15, 2014. These conditions can be shown in Fig. 8, which is one of the nearest settlement to the banks of the Tondano river. The results of the flood modeling with the return periods and the height flood inundation scenarios can be shown in Figs. 9 and 10.

The implementation of flood inundation modeling can be used to determine the flood damage assessment on LULC affected by flooding in the research area. This result can be predicted on the impact of floods in each LULC class for year 2015, 2025, 2035 and 2050. Thus, the impact of floods in the future can be predicted. The results of overlay between the flood inundation maps with the LULC maps have produced LULC information affected by floods, which can be presented in Fig. 11. Meanwhile, the results of the damage exposure estimation at each flood scenario that is calculated based on the market value per hectare in each LULC class can be presented in Tables 9, 10, 11, 12, 13 and 14. It can be shown that the total of flood damage exposure for the water level scenario $\mathrm{Hc}=3 \mathrm{~m}$ with the return periods $2,5,10,20,50$ and 100 years are more than $€ 424$, €438, €499, €509, €511 and €520 million, respectively. Meanwhile, for the water level scenario $\mathrm{Hc}=5 \mathrm{~m}$ with the return periods $2,5,10,20,50$ and 100 years are more than €915, €922, €924, €947, €957 and €958 million, respectively. 


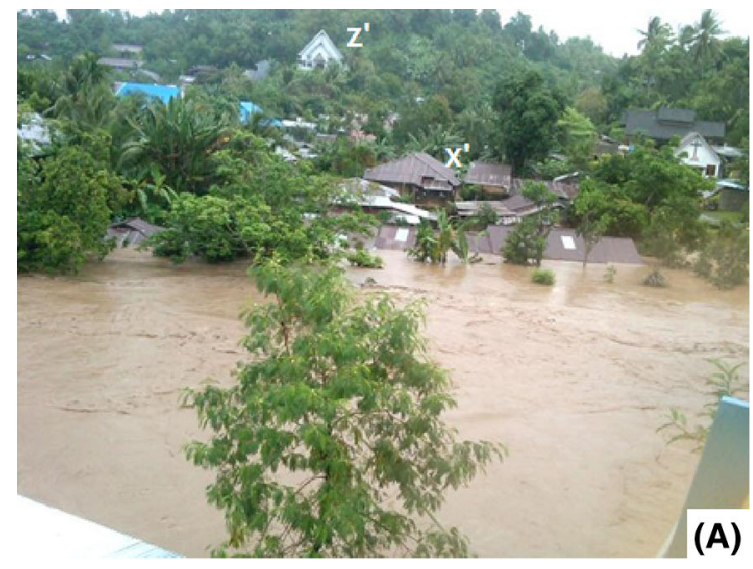

Fig. 7 The height of flood inundation of $3 \mathrm{~m}$ at the time of the flood event on January 15, 2014. a During flood in Tikala river, Malendeng village. b Post flood in Tikala river, Malendeng village (photos from

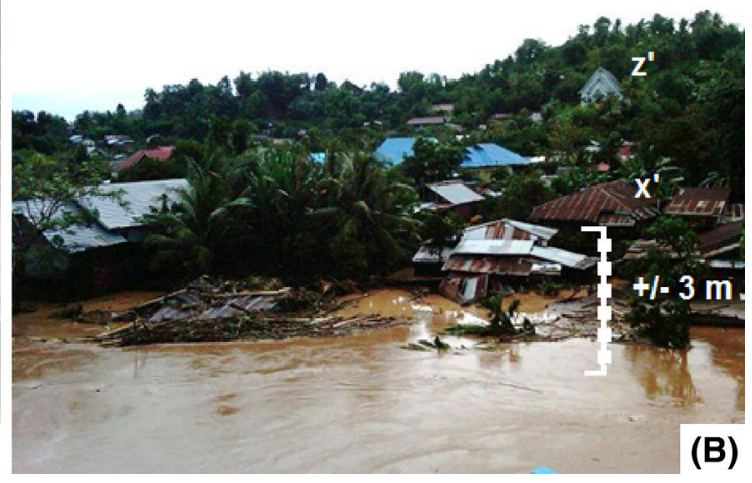

The Management Center of Tondano Watershed-Ministry of Forestry 2014)

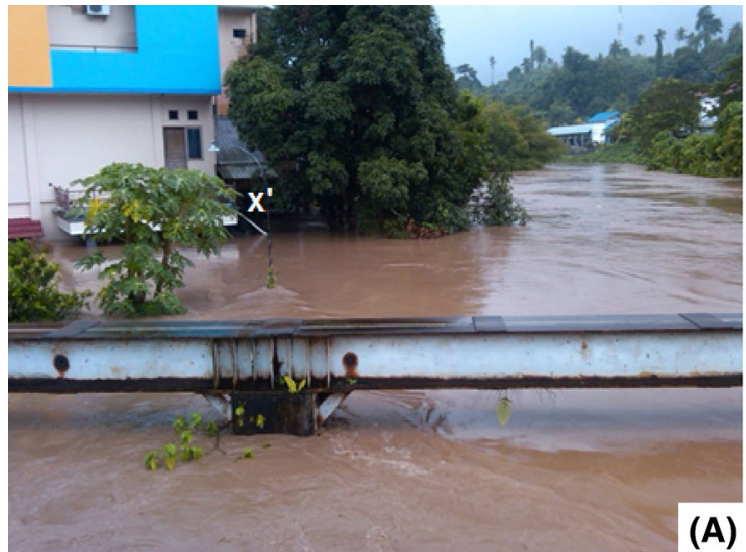

(A)

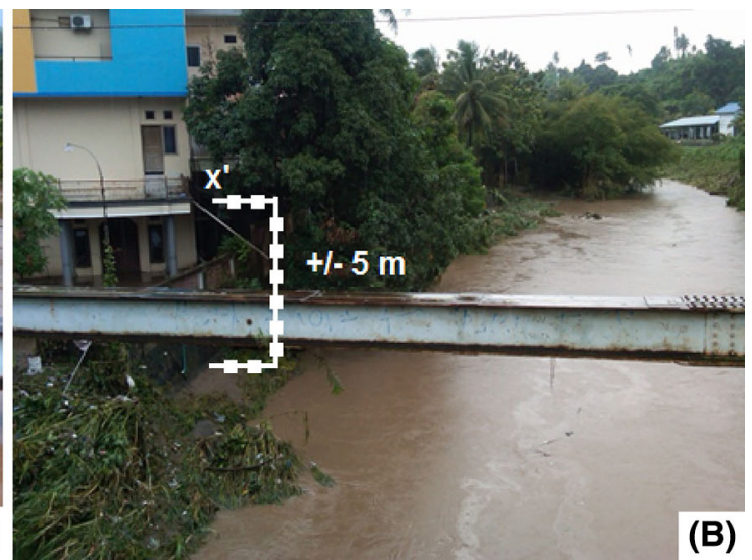

(B)

Fig. 8 The height of flood inundation of $5 \mathrm{~m}$ at the time of the flood event on January 15, 2014. a During flood in Tondano river, Kairagi village. b Post flood in Tondano river, Kairagi village (photos from The Management Center of Tondano Watershed-Ministry of Forestry 2014)

\section{Discussion}

This research has produced information related to the dynamics of LULC change modeling and their implication for the flood damage assessment. In this section, we will discuss related limitations, uncertainty and future direction for the use of methods that have been applied in the research area.

The results of LULC information that has been generated in this research, there are limitations. These limitations are related to the use of Markov-CA approach which does not include the parameters and factors that could affect or inhibit the occurrence of the LULC change in the research area. Thus, the resulting of LULC map updates in the next few years are assumed to be linear and the results are a scenario with a normally indication, without any triggering factor and inhibit the occurrence of the LULC change. This can be shown on difference in the average area change between the results of LULC classification in 1997-2015 with the results of LULC modeling in 2015-2050. Where, the average area change of the LULC classification in 1997-2015 is tending to relatively large. Meanwhile, the average area change of the LULC modeling in 2015-2050 is tending to relatively small. As an example for class of forest and paddy fields, the LULC classification in 1997-2015 had a rate of change: 121.82 and $108.13 \mathrm{ha} /$ year, respectively. Meanwhile, the LULC modeling in 2015-2050 had a rate of change: 10.52, 14.49 ha/year, respectively. It can be used as input for future research in the research area to add the factors and parameters that can trigger factor and inhibit the occurrence of the LULC change. Thus, the information on the prediction and modeling LULC maps that will be able to provide good accuracy and precision (note: the result of the accuracy by using cross-correlation matrix between the LULC models in 2015 with the LULC reference in 2015 is $75.88 \%$ ), as has 

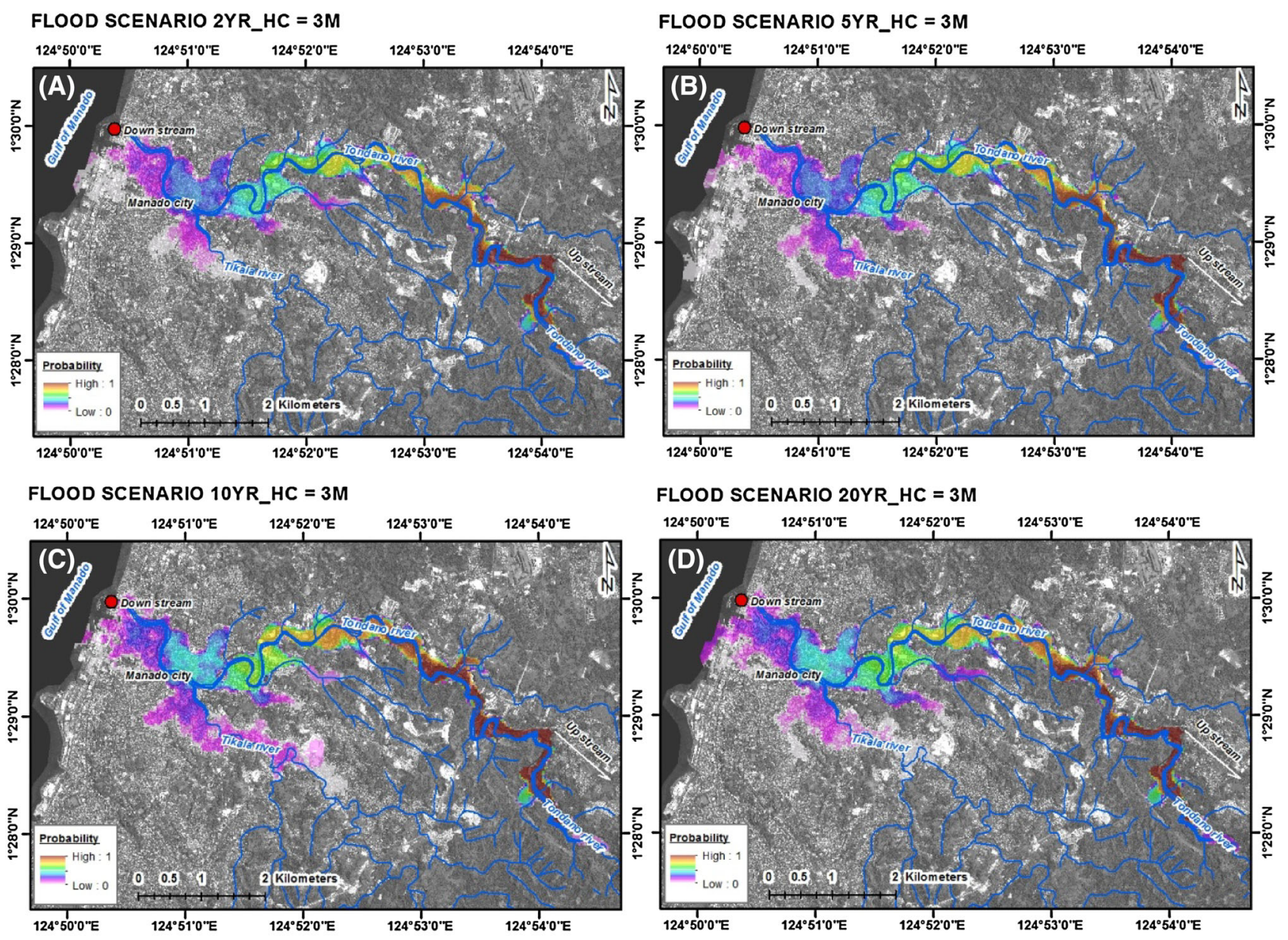

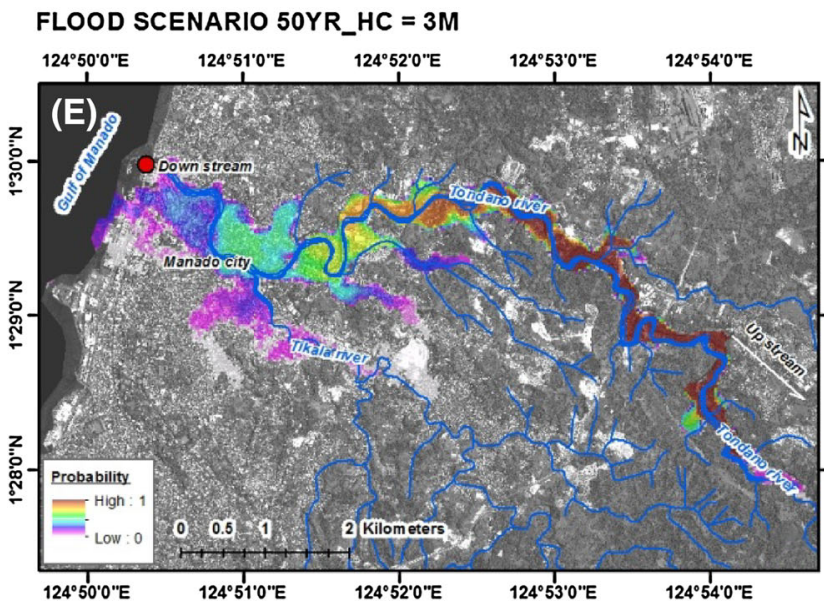

Fig. 9 The results of flood inundation modeling using the Monte Carlo algorithm with the height flood scenario $\mathrm{Hc}=3 \mathrm{~m}$. a Flood scenario return period 2 years. b Flood scenario return period 5 years.

been done by several previous studies (e.g., Guan et al. 2011; Halmy et al. 2015)

The limitations of the flood inundation models were used in this research, namely: (a) modeling was performed on the segment of the Tondano river with a range point of
FLOOD SCENARIO 100YR_HC $=3 \mathrm{M}$

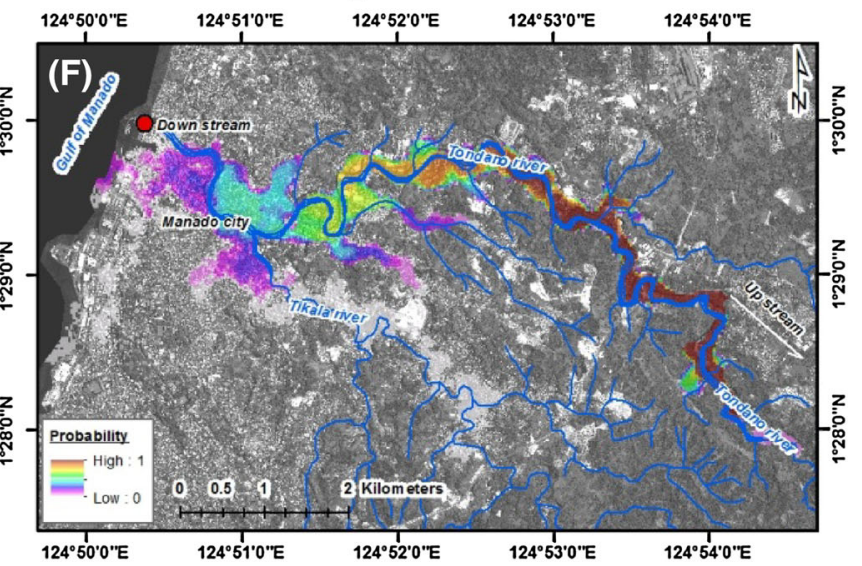

c Flood scenario return period 10 years. d Flood scenario return period 20 years. e Flood scenario return period 50 year. f Flood scenario return period 100 years

downstream boundary to the point of the upper boundary Tondano river, (b) the Tikala river has been modeled as lateral inflow into Tondano river, (c) the existence of drainage, tributary and bridges in the segment of the Tondano river were ignored. These limitations have the same with the 

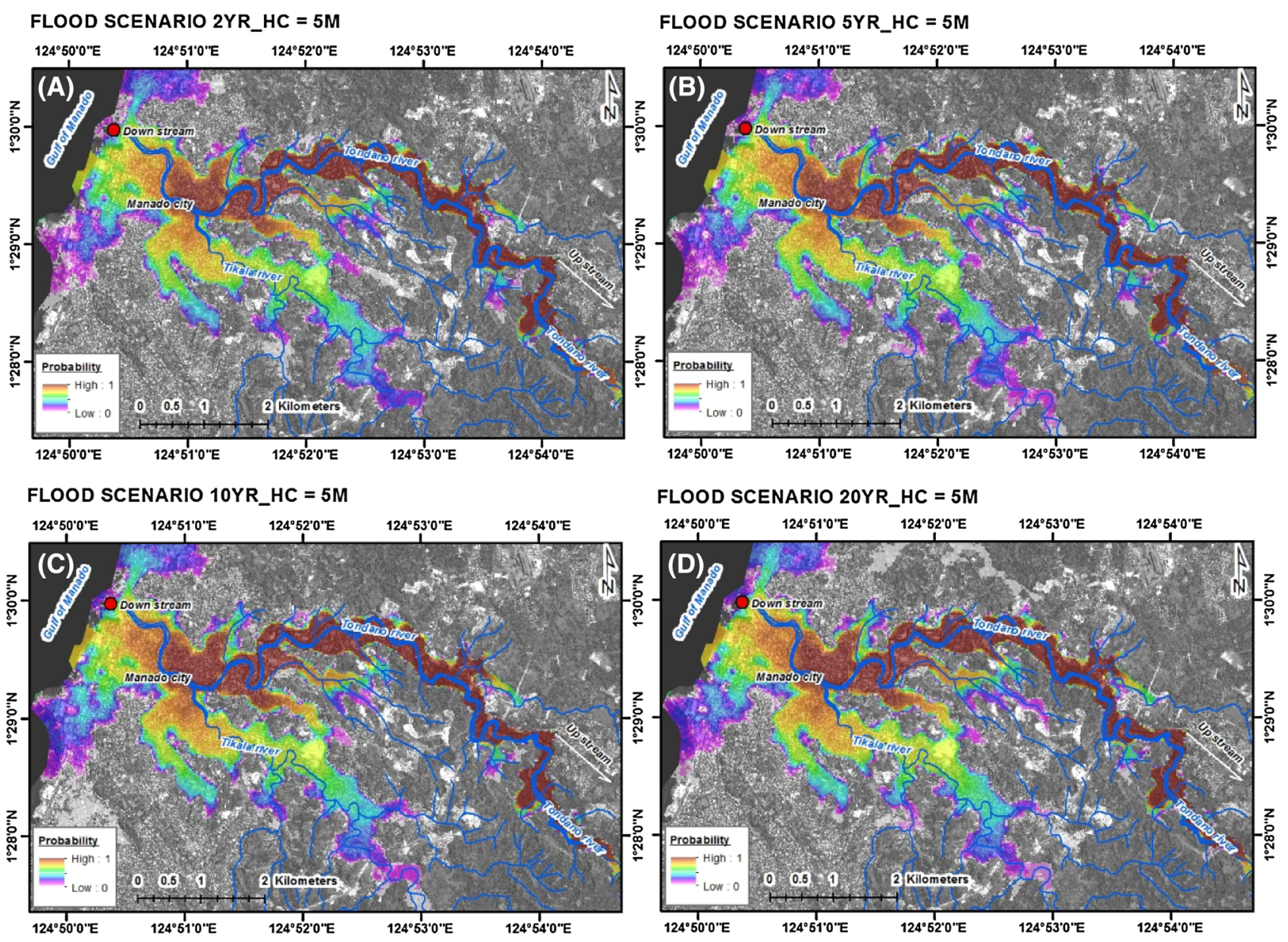

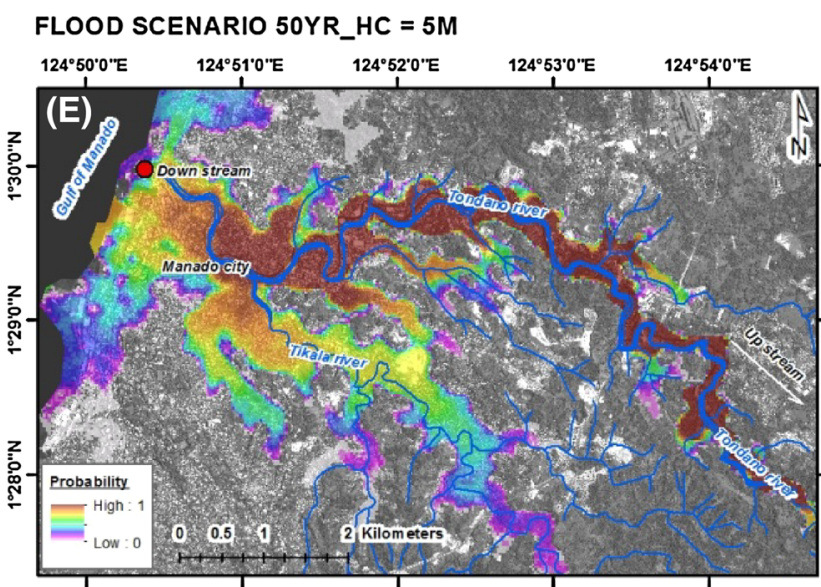

$124^{\circ} 50^{\circ} 0^{\circ} \mathrm{E} \quad 124^{\circ} 51^{\circ} 0^{\circ} \mathrm{E} \quad 124^{\circ} 52^{\circ} 0^{\circ} \mathrm{E} \quad 124^{\circ} 53^{\circ} \mathrm{O}^{\circ \mathrm{E}} \quad 124^{\circ} 54^{\circ} \mathrm{O}^{\circ} \mathrm{E}$

Fig. 10 The results of flood inundation modeling using the Monte Carlo algorithm with the height flood scenario $\mathrm{Hc}=5 \mathrm{~m}$. a Flood scenario return period 2 years. b Flood scenario return period 5 years.

research created by Nanlohy et al. (2008). Map of flood inundation models that have been created by using the Monte Carlo approach presents a static and not dynamic modeling. In addition, the limitations of the resulting model can only present the distribution of flood inundation that is shown with

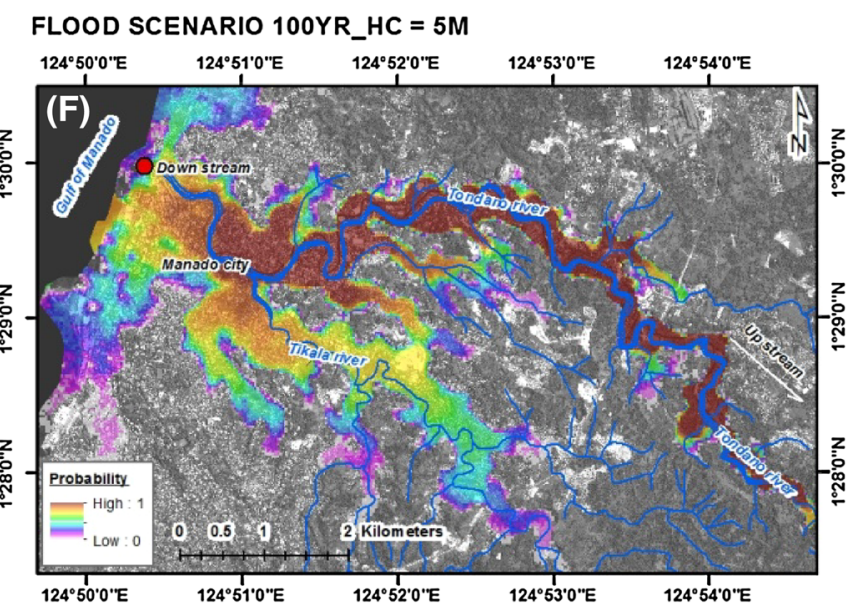

c Flood scenario return period 10 years. d Flood scenario return period 20 years. e Flood scenario return period 50 years. f Flood scenario return period 100 years

a probability value at each scenario in the running. Where, at a value of 0 indicates a low probability and value of 1 indicates a high probability. Thus, the depth of flood information is not available in this model. However, the modeling can provide relatively quick benefits of generating flood 
(Ha) (A)

(Ha)
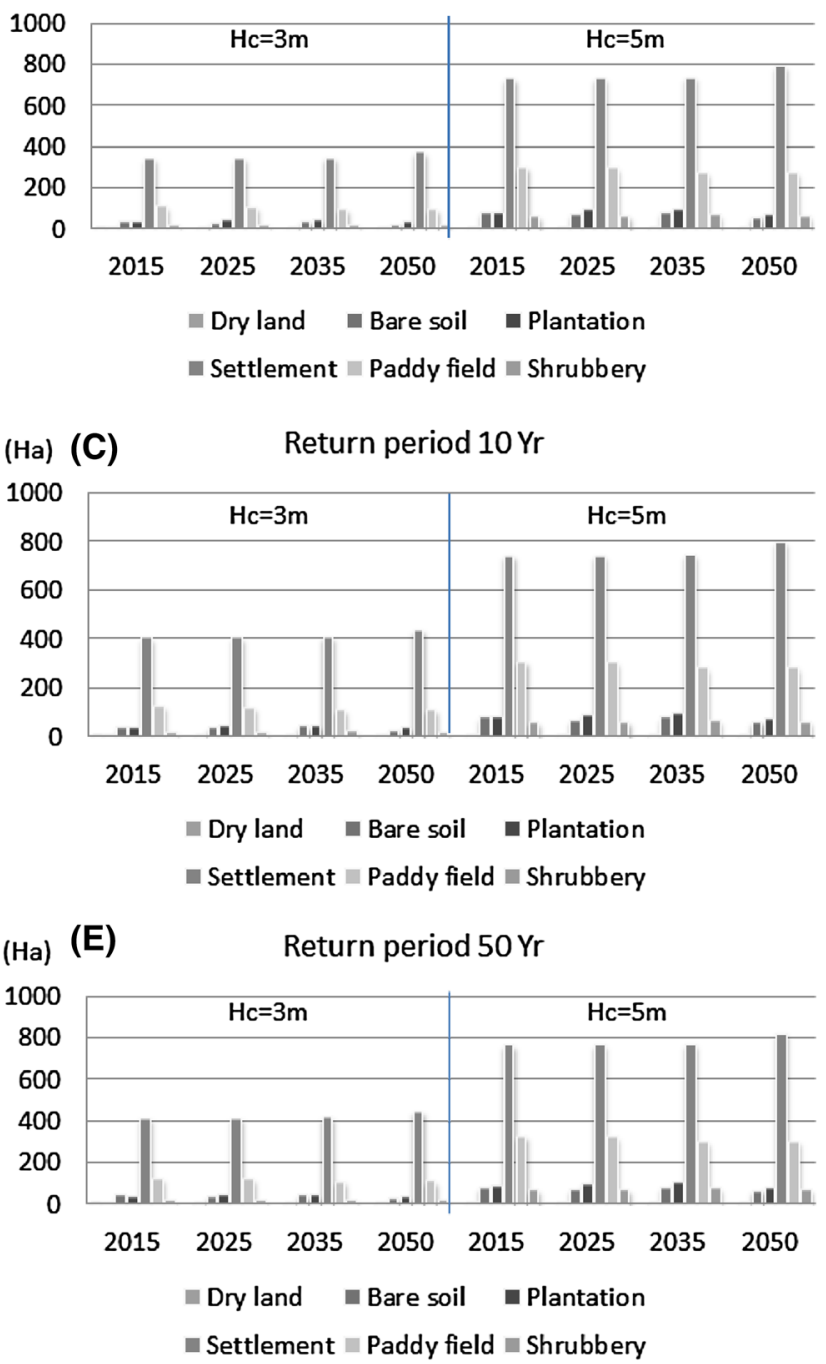

Fig. 11 The results of overlay between the flood inundation maps with the LULC maps have produced LULC information affected by floods in the research area. a Flood scenario return period 2 years.
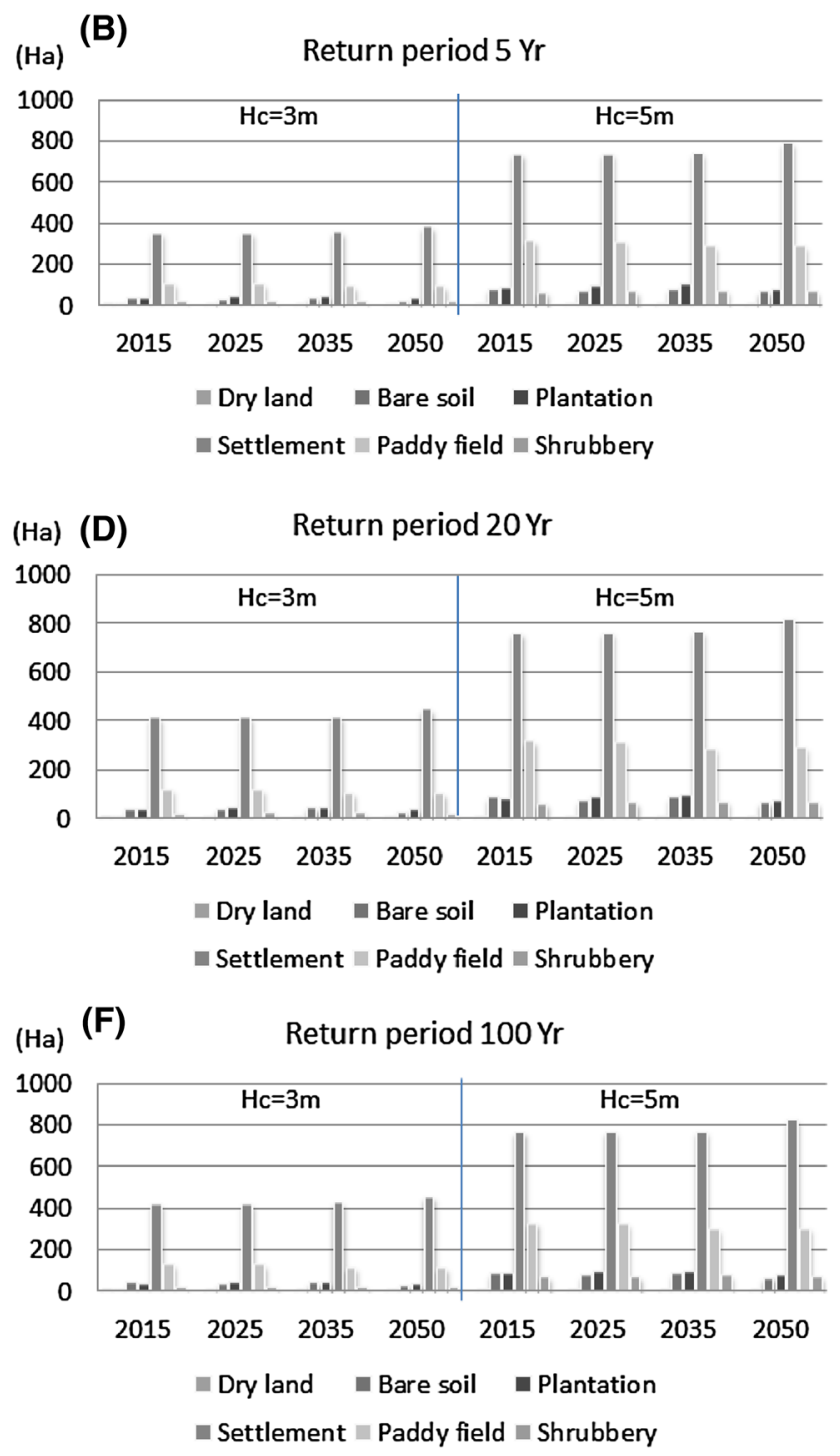

b Flood scenario return period 5 years. c Flood scenario return period 10 years. d Flood scenario return period 20 years. e Flood scenario return period 50 years. f Flood scenario return period 100 years
Table 9 The damage exposure estimation of the flood scenario return period 2 years and LULC model prediction in 2015,2025 , 2035 and 2050 (value in 1000 EUR)

\begin{tabular}{|c|c|c|c|c|c|c|c|c|}
\hline \multirow[t]{2}{*}{ LULC } & \multicolumn{4}{|c|}{ Return period 2 years, $\mathrm{Hc}=3 \mathrm{~m}$} & \multicolumn{4}{|c|}{ Return period 2 years, $\mathrm{Hc}=5 \mathrm{~m}$} \\
\hline & 2015 & 2025 & 2035 & 2050 & 2015 & 2025 & 2035 & 2050 \\
\hline Dry land & 232 & 224 & 264 & 192 & 640 & 600 & 808 & 400 \\
\hline Bare soil & 61 & 54 & 65 & 37 & 137 & 120 & 138 & 98 \\
\hline Plantation & 2992 & 3472 & 3464 & 2784 & 6648 & 7528 & 7680 & 5896 \\
\hline Settlement & 412,680 & 414,600 & 417,960 & 449,760 & 883,320 & 886,080 & 891,360 & 956,880 \\
\hline Paddy fields & 8784 & 8520 & 7656 & 7720 & 24,240 & 23,896 & 22,000 & 22,080 \\
\hline Shrubbery & 31 & 33 & 34 & 30 & 106 & 109 & 117 & 110 \\
\hline Total & 424,780 & 426,903 & 429,443 & 460,523 & 915,091 & 918,334 & 922,103 & 985,464 \\
\hline
\end{tabular}

inundation models. It is suitable for rapid mapping required during emergency response. The results of the flood inundation modeling have not been validated in this research.
Thus, the field of measurement and observation for model validation is required and recommended in the future research. 
Table 10 The damage exposure estimation of the flood scenario return period 5 years and LULC model prediction in 2015, 2025, 2035 and 2050 (value in 1000 EUR)
Table 11 The damage exposure estimation of the flood scenario return period 10 years and LULC model prediction in 2015, 2025, 2035 and 2050 (value in 1000 EUR)
Table 12 The damage exposure estimation of the flood scenario return period 20 years and LULC model prediction in 2015, 2025, 2035 and 2050 (value in 1,000 EUR)

\begin{tabular}{|c|c|c|c|c|c|c|c|c|}
\hline \multirow[t]{2}{*}{ LULC } & \multicolumn{4}{|c|}{ Return period 5 years, $\mathrm{Hc}=3 \mathrm{~m}$} & \multicolumn{4}{|c|}{ Return period 5 years, $\mathrm{Hc}=5 \mathrm{~m}$} \\
\hline & 2015 & 2025 & 2035 & 2050 & 2015 & 2025 & 2035 & 2050 \\
\hline Dry land & 240 & 224 & 256 & 200 & 768 & 696 & 952 & 440 \\
\hline Bare soil & 58 & 51 & 62 & 35 & 139 & 118 & 139 & 114 \\
\hline Plantation & 3040 & 3520 & 3528 & 2816 & 6904 & 7936 & 8112 & 6136 \\
\hline Settlement & 426,360 & 427,680 & 431,760 & 462,960 & 889,560 & 891,000 & 893,400 & 955,440 \\
\hline Paddy fields & 8704 & 8432 & 7632 & 7640 & 25,384 & 25,096 & 23,280 & 23,312 \\
\hline Shrubbery & 26 & 29 & 28 & 26 & 112 & 117 & 125 & 116 \\
\hline Total & 438,428 & 439,936 & 443,266 & 473,677 & 922,867 & 924,963 & 926,008 & 985,558 \\
\hline
\end{tabular}

\begin{tabular}{|c|c|c|c|c|c|c|c|c|}
\hline \multirow[t]{2}{*}{ LULC } & \multicolumn{4}{|c|}{ Return period 10 years, $\mathrm{Hc}=3 \mathrm{~m}$} & \multicolumn{4}{|c|}{ Return period 10 years, $\mathrm{Hc}=5 \mathrm{~m}$} \\
\hline & 2015 & 2025 & 2035 & 2050 & 2015 & 2025 & 2035 & 2050 \\
\hline Dry land & 296 & 264 & 320 & 200 & 648 & 624 & 856 & 344 \\
\hline Bare soil & 70 & 62 & 73 & 43 & 133 & 116 & 134 & 103 \\
\hline Plantation & 3112 & 3616 & 3584 & 2912 & 6400 & 7328 & 7544 & 5688 \\
\hline Settlement & 485,880 & 488,520 & 492,360 & 525,000 & 892,920 & 893,400 & 897,120 & 960,720 \\
\hline Paddy fields & 10,008 & 9688 & 8816 & 8936 & 24,672 & 24,392 & 22,536 & 22,624 \\
\hline Shrubbery & 32 & 34 & 34 & 32 & 100 & 104 & 113 & 104 \\
\hline Total & 499,398 & 502,184 & 505,187 & 537,123 & 924,873 & 925,964 & 928,303 & 989,583 \\
\hline
\end{tabular}

\begin{tabular}{|c|c|c|c|c|c|c|c|c|}
\hline \multirow[t]{2}{*}{ LULC } & \multicolumn{4}{|c|}{ Return period 20 years, $\mathrm{Hc}=3 \mathrm{~m}$} & \multicolumn{4}{|c|}{ Return period 20 years, $\mathrm{Hc}=5 \mathrm{~m}$} \\
\hline & 2015 & 2025 & 2035 & 2050 & 2015 & 2025 & 2035 & 2050 \\
\hline Dry land & 296 & 264 & 336 & 208 & 704 & 648 & 880 & 416 \\
\hline Bare soil & 71 & 62 & 74 & 45 & 146 & 128 & 146 & 111 \\
\hline Plantation & 3216 & 3712 & 3704 & 3000 & 6480 & 7400 & 7640 & 5712 \\
\hline Settlement & 496,320 & 498,120 & 501,600 & 538,680 & 914,400 & 916,560 & 921,480 & 987,240 \\
\hline Paddy fields & 9616 & 9408 & 8456 & 8336 & 25,424 & 25,024 & 23,080 & 23,192 \\
\hline Shrubbery & 33 & 35 & 36 & 32 & 106 & 112 & 120 & 111 \\
\hline Total & 509,551 & 511,601 & 514,206 & 550,301 & 947,260 & 949,872 & 953,345 & $1,016,783$ \\
\hline
\end{tabular}

Table 13 The damage exposure estimation of the flood scenario return period 50 years and LULC model prediction in 2015, 2025, 2035 and 2050 (value in 1000 EUR)

\begin{tabular}{|c|c|c|c|c|c|c|c|c|}
\hline \multirow[t]{2}{*}{ LULC } & \multicolumn{4}{|c|}{ Return period 50 years, $\mathrm{Hc}=3 \mathrm{~m}$} & \multicolumn{4}{|c|}{ Return period 50 years, $\mathrm{Hc}=5 \mathrm{~m}$} \\
\hline & 2015 & 2025 & 2035 & 2050 & 2015 & 2025 & 2035 & 2050 \\
\hline Dry land & 328 & 304 & 360 & 208 & 712 & 696 & 928 & 416 \\
\hline Bare soil & 69 & 61 & 73 & 43 & 138 & 120 & 140 & 110 \\
\hline Plantation & 2992 & 3480 & 3480 & 2792 & 7024 & 8032 & 8176 & 6200 \\
\hline Settlement & 498,600 & 499,560 & 504,120 & 538,680 & 923,520 & 925,680 & 927,720 & 992,760 \\
\hline Paddy fields & 9880 & 9680 & 8728 & 8768 & 26,368 & 26,016 & 24,080 & 24,272 \\
\hline Shrubbery & 28 & 30 & 30 & 27 & 116 & 118 & 130 & 120 \\
\hline Total & 511,897 & 513,115 & 516,790 & 550,518 & 957,878 & 960,662 & 961,174 & $1,023,878$ \\
\hline
\end{tabular}

Implementation of the uses of LULC and flood inundation modeling was estimated flood damage assessment in the research area. The process is done in a simple, namely: overlay between the flood inundation model with the LULC model that has been calculated for the next few years. Thus, the information of LULC affected by flooding can be determined in the research area. Estimates of flood damage exposure for the next few years has been calculated based on the asset value per hectare under current conditions in each LULC class. The results obtained by the 
Table 14 The damage exposure estimation of the flood scenario return period 100 years and LULC model prediction in 2015, 2025, 2035 and 2050 (value in 1000 EUR)

\begin{tabular}{|c|c|c|c|c|c|c|c|c|}
\hline \multirow[t]{2}{*}{ LULC } & \multicolumn{4}{|c|}{ Return period 100 years, $\mathrm{Hc}=3 \mathrm{~m}$} & \multicolumn{4}{|c|}{ Return period 100 years, $\mathrm{Hc}=5 \mathrm{~m}$} \\
\hline & 2015 & 2025 & 2035 & 2050 & 2015 & 2025 & 2035 & 2050 \\
\hline Dry land & 296 & 288 & 376 & 208 & 720 & 672 & 912 & 42 \\
\hline Bare soil & 70 & 61 & 71 & 45 & 147 & 129 & 147 & 111 \\
\hline Plantation & 3144 & 3608 & 3592 & 2896 & 6880 & 7872 & 7984 & 6032 \\
\hline Settlement & 506,040 & 506,880 & 512,760 & 547,080 & 923,880 & 925,920 & 929,280 & 997,440 \\
\hline Paddy fields & 10,472 & 10,320 & 9240 & 9184 & 26,512 & 26,160 & 24,192 & 24,416 \\
\hline Shrubbery & 33 & 35 & 37 & 32 & 117 & 120 & 132 & 121 \\
\hline Total & 520,054 & 521,191 & 526,075 & 559,446 & 958,256 & 960,873 & 962,647 & $1,028,544$ \\
\hline
\end{tabular}

flood scenario in extreme conditions for the return period of 100 year, the total of flood damage exposure can be estimated more than $€ 520$ million for the water level scenario $\mathrm{Hc}=3 \mathrm{~m}$ and $€ 958$ million for the water level scenario $\mathrm{Hc}=5 \mathrm{~m}$. The market value of each class of LULC has not been done in detail. Thus, the limitations can be shown by the incorporation of market value in agricultural class (e.g., paddy fields, plantations and dry land) and the open area class (e.g., bare soil and shrubbery). It is necessary and recommended in the future research to focus in calculating the asset value for each LULC class in detail.

\section{Conclusion}

Markov-CA and Monte Carlo algorithm approaches have been successfully used in this research to create LULC and flood modelling, which can then be implemented to estimate the flood damage assessment for the next few years. The utilization of multi-temporal remotely sensed Landsat and ASTER GDEM have supported the acquisition of input data for modeling created by Markov-CA and Monte Carlo algorithm approaches. The results of LULC and flood modeling in this research could be used to support the mapping at a scale of 1:25,000-1:50,000. In the future research, it is advisable and recommended to use multitemporal remotely sensed data with high resolution, such as Ikonos, Quickbird, Worldview, Pleiades and others. Thus, the need modeling for detailed mapping or less than scale $1: 10,000$ can be fulfilled. In addition, the use of stereo imagery from SPOT 6 and 7 with a spatial resolution of $6 \mathrm{~m}$ can be used for detailing topography information or DEM in the research area. The requirement of DEM data with a spatial resolution of less than $10 \mathrm{~m}$ is needed in flood modeling. Thus, the accuracy of the results of flood modeling can be improved and increased. The results of LULC modeling and their implication not only used for estimating the flood damage assessment, but also the results can be used to predict the flow discharge of flooding due to LULC changes for the next few years. Thus, in the future research can be suggested and recommended to predict the flow discharge of flooding due to LULC changes, and the results can be used as one of the stages in the flood mitigation effort in the research area.

Acknowledgments This paper is a part of the research activities entitled "The utilization of remotely sensed data to support analysis of floods in Indonesia". This research was funded by the budget of DIPA LAPAN activities in 2015, Remote Sensing Application Center, Indonesian National Institute of Aeronautics and Space (LAPAN). Thanks go to Dr. M. Rokhis Khomarudin (Director of Remote Sensing Application Center, LAPAN) who has supported the implementation of this research. Drs. Taufik Maulana, MBA., Dr. Wikanti Asriningrum and colleagues at the Remote Sensing Application Center, LAPAN for support, discuss and give suggestions in this research. Landsat 5 MSS and Landsat 7 TM images were provided by the U.S. Geological Survey (USGS). Landsat 8 LDCM images were provided by LAPAN. ASTER GDEM data were provided by the Japan Space Systems (Japan-US ASTER Science Team).

\section{References}

Arsanjani JJ, Helbich M, Kainz W, Boloorani AD (2013) Integration of logistic regression, Markov chain and cellular automata models to simulate urban expansion. Int J Appl Earth Obs Geoinf 21:265-275

Beckers A, Dewals B, Erpicum S, Dujardin S, Detrembleur S, Teller J, Pirotton M, Archambeau P (2013) Contribution of land use changes to future flood damage along the river Meuse in the Walloon region. Nat Hazards Earth Syst Sci 13:2301-2318

Behera MD, Borate SN, Panda SN, Behera PR, Roy PS (2012) Modelling and analyzing the watershed dynamics using Cellular Automata (CA)-Markov model-a geo-information based approach. J Earth Syst Sci 121:1011-1024

Chavez PS Jr (1988) An improved dark-object subtraction technique for atmospheric scattering correction of multispectral data. Remote Sens Environ 24:459-479

Chen X, Yu SX, Zhang YP (2013) Evaluation of spatio temporal dynamics of simulated land use/cover in China using a probabilistic Cellular Automata-Markov model. Pedosphere 23(2):243-255

Cihlar J (2000) Land cover mapping of large areas from satellites: status and research priorities. Int J Remote Sens 21:1093-1114

Dayantolis W, Fitri HT (2014) Overview climatological flooding on January 15, 2014 in Manado. Category Archives: Manado. https://bencanasulut.wordpress.com/category/manado. Accessed 08 Jan 2015 (in Indonesian)

Felpeto A (2009) VORIS a GIS-based tool for volcanic hazard assessment. User's Guide Version 2.0.1 
Felpeto A, Matri J, Ortiz R (2007) Automatic GIS-based system for volcanic hazard assessment. J Volcanol Geotherm Res 166:106-116

Gong W, Yuan L, Fanc W, Stott P (2015) Analysis and simulation of land use spatial pattern in Harbin prefecture based on trajectories and cellular automata-Markov modelling. Int J Appl Earth Obs Geoinf 34:207-216

Guan D, Li HF, Inohae T, Su W, Nagaie T, Hakao K (2011) Modeling urban land use change by the integration of cellular automaton and Markov model. Ecol Model 222:3761-3772

Hall R, Wilson MEJ (2000) Neogene sutures in eastern Indonesia. J Asian Earth Sci 18(6):781-808

Halmy MWA, Gessler PE, Hicke JA, Salem BB (2015) Land use/land cover change detection and prediction in the northwestern coastal desert of Egypt using Markov-CA. Appl Geogr 63:101-112

Herath (2003) Flood damage estimation of an urban catchment using remote sensing and GIS. International Training Program on Total Disaster Risk Management

Huang SL, Wang SH, Budd WW (2009) Sprawl in Taipei's periurban zone: responses to spatial planning and implications for adapting global environmental change. Landsc Urban Plan 90(1-2):20-32

Indonesian of Central Agency Statistics (BPS) (2014) Statistics of Minahasa District

Indonesian of Central Agency Statistics (BPS) (2014) Statistics of Minahasa Utara District

Indonesian of Central Agency Statistics (BPS) (2014) Statistics of Tomohon District

Indonesian of Central Agency Statistics (BPS) (2014) Statistics of Manado District

Joling RJ (2013) Adding more detail to potential flood damage assessment: An object based approach. Thesis BSc Aarde and Economie. Vrije Universiteit Amsterdam Faculteit Aard-en Levenswetenschappen

Jonge T, Kok M, Hogeweg M (1996) Modelling floods and damage assessment using GIS. HydroGIS 96: application of geographic information systems in hydrology and water resources management. In: Proceedings of the Vienna Conference. IAHS Publ 235

Jongman B, Kreibich H, Apel H, Barredo JI, Bates PD, Feyen L, Gericke A, Neal J, Aerts JCJH, Ward PJ (2012) Comparative flood damage model assessment: towards a European approach. Nat Hazards Earth Syst Sci 12:3733-3752

Kalyanapu AJ (2011) Monte Carlo based flood risk analysis using a graphics processing unit-enhanced two-dimensional flood model. Dissertation. Department of Civil and Environmental Engineering. The University of Utah

Lambin EF (1997) Modelling and monitoring land-cover change processes in tropical regions. Prog Phys Geogr 21:375-393

Luca C, Michele M, Silvia M (2013) Investigating the relationship between land cover and vulnerability to climate change in Dares Salaam. Working Paper, Rome: Sapienza University

Marfai MA, King L (2007) Tidal inundation mapping under enhanced land subsidence in Semarang, Central Java Indonesia. Nat Hazards 44:93-109

Metzler SM (2011) Land use interpretation in flood damage estimation. Master's Theses and Graduate Research, San Jose State University. Paper 4103

Mousivand AJ, Sarab AA, Shayan S (2007) A new approach of predicting land use and land cover changes by satellite imagery and Markov chain model (case study: Tehran). MSc Thesis. Tarbiat Modares University, Tehran, Iran

Nanlohy BJB, Jayadi R, Istiarto (2008) The study of flood control alternatives Tondano river in Manado city. Forum civil engineering XVIII:756-767 (in Indonesian)
NASA (2011) Landsat 7 science data users handbook. Maryland: Landsat Project Science Office at NASA's Goddard Space Flight Center in Greenbelt

Nejadi A, Jafari HR, Makhdoum MF, Mahmoudi M (2012) Modeling plausible impacts of land use change on wildlife habitats, application and validation: lisar protected area, Iran. Int $\mathrm{J}$ Environ Res 6(4):883-892

Pouliot D, Latifovic R, Zabcic N, Guindon L, Olthof I (2014) Development and assessment of a $250 \mathrm{~m}$ spatial resolution MODIS annual land cover time series (2000-2011) for the forest region of Canada derived from change-based updating. Remote Sens Environ 140:731-743

Richards JA, Jia X (2006) Remote sensing digital image analysis: an introduction. Springer, Berlin

Rogan J, Chen D (2004) Remote sensing technology for mapping and monitoring land-cover and land-use change. Prog Plan 61:301-325

Seniarwan Baskoro DPT, Gandasasmita K (2013) Spatial modelling of flood inundation: case study Mangottong river area, Sinjay Regency, South Sulawesi Province. Sci J Globe 15(1):62-67 (in Indonesian)

Shooshtari SJ, Gholamalifard M (2015) Scenario-based land cover change modeling and its implications for landscape pattern analysis in the Neka Watershed, Iran. Remote Sens Appl Soc Environ 1:1-19

Smemoe CM, Nelson EJ, Zundel AK, Miller W (2007) Demonstrating floodplain uncertainty using flood probability maps. J Am Water Resour Assoc 43(2):359-371

Sompotan AF (2012) Gological stucture of Sulawesi Struktur Geologi Sulawesi. Earth Sciences Library. Bandung Institute of Technology (ITB) (in Indonesian)

Stürck J, Schulp CJE, Verburg PH (2015) Spatio-temporal dynamics of regulating ecosystem services in Europe e The role of past and future land use change. Appl Geogr 63:121-135

Su MD, Kang JL, Chang LF, Chen AS (2005) A grid-based gis approach to regional flood damage assessment. J Mar Sci Technol 13(3):184-192

Sun H, Forsythe W, Waters N (2007) Modeling urban land use change and urban sprawl: Calgary, Alberta, Canada. Netw Spat Econ 7(4):353-376

Sylvertown J, Hotlier S, Johnson J, Dale P (1992) Cellular automaton models of inter specific competition for space the effect of pattern on process. J Ecol 80:527-534

The Management Center of Tondano Watershed-Ministry of Forestry (2014) Characteristics of Tondano watershed. Final report (in Indonesian)

Thomas H, Laurence HM (2006) Modeling and projecting land-use and land-cover changes with a cellular automaton in considering landscape trajectories: An improvement for simulation of plausible future states. EARSeLeProc 5:63-76

USGS (2013) Landsat missions: frequently asked questions about the Landsat missions US Geological Survey. Last modified: 5/30/ 123. Landsat.usgs.gov

USGS (2013) Using the US Geological survey Landsat 8 product. Last modified: 5/30/123. Landsat7.usgs.gov

Wang X, Zhang C (2001) A dynamic modelling approach to simulating socioeconomic effects on landscape changes. Ecol Model 140:141-162

Wang SQ, Zheng XQ, Zang XB (2012) Accuracy assessments of land use change simulation based on Markov-cellular automata model. Proc Environ Sci 13:1238-1245

Ward PJ, Marfai MA, Yulianto F, Hizbaron DR, Aerts JCJH (2010) Coastal inundation and damage exposure estimation: a case study for Jakarta. Nat Hazards 56:899-916 
Ward PJ, Moel H, Aerts JCJH (2011) How are flood risk estimates affected by the choice of return-periods? Nat Hazards Earth Syst Sci 11:3181-3195

Wehmann A, Liu D (2015) A spatial-temporal contextual Markovian kernel method for multi-temporal land cover mapping. ISPRS J Photogramm Remote Sens 107:77-89

Wu Q, Li H, Wang R, Paulussen J, He Y, Wang M et al (2006) Monitoring and predicting land use change in Beijing using remote sensing and GIS. Landsc Urban Plan 78:322-333

Yan WY, Shaker A, El-Ashmawy N (2015) Urban land cover classification using airborne LiDAR data: a review. Remote Sens Environ 158:295-310

Yang H, Du L, Guo H, Zhang J (2011) Tai'an land use analysis and prediction based on RS and Markov model. Proc Environ Sci $10: 2625-2630$

Yang X, Zheng XC, Chen R (2014) A land use change model: integrating landscape pattern indexes and Markov-CA. Ecol Model 283:1-7
Yen NTM, Anh TV (2010) Application of remote sensing data for mapping of damage assessment of flood to the land cover, an experiment in Phu Yen province, Vietnam. In: International Symposium on Geoinformatics for Spatial Infrastructure Development in Earth and Allied Sciences

Yulianto F, Sofan P, Zubaidah A, Sukowati KAD, Pasaribu JM, Khomarudin MR (2015a) Detecting areas affected by flood using multi-temporal ALOS PALSAR remotely sensed data in Karawang, West Java, Indonesia. Nat Hazards 77:959-985

Yulianto F, Tjahjono B, Anwar S (2015b) The applications of Monte Carlo algorithm and energy con model to produce the probability of block-and-ash flows of the 2010 eruption of Merapi volcano in Central Java, Indonesia. Arab J Geosci 8:4717-4739

Zhu J (2010) GIS based urban flood inundation modeling. Second WRI Glob Congr Intell Syst 2:140-143 